\title{
New breeding objectives and selection indices for the Australian dairy industry
}

\author{
T. J. Byrne,${ }^{* 1}$ B. F. S. Santos, ${ }^{*} \dagger$ P. R. Amer, ${ }^{*}$ D. Martin-Collado, ${ }^{*}$ J. E. Pryce, $\ddagger$ and M. Axford§ \\ *AbacusBio Limited, Dunedin 9016, New Zealand \\ †School of Environmental and Rural Science, University of New England, Armidale, NSW 2351, Australia \\ ‡Department of Economic Development, Jobs, Transport and Resources and La Trobe University, AgriBio, Bundoora, VIC 3083, Australia \\ §Australian Dairy Herd Improvement Scheme, Melbourne, VIC 3000, Australia
}

\begin{abstract}
This study comprises an update of the economic values for dairy traits for the Australian industry and the formulation of updated selection indices. An economic model, which calculates partial economic values for each trait individually, was developed to determine the economic implications of selective dairy breeding, based on the effect of trait changes on the profit of commercial dairy farms in Australia. Selection indices were developed from economic values, which were transformed into base economic weights by including the discounted genetic expressions coefficients. Economic weights (in Australian dollars) were $1.79,6.92,-0.10,-5.44,8.84$, $7.68,1.07,4.86,1.91,3.51,4.90,0.31,2.03,2.00$, and 0.59 , for milk fat $(\mathrm{kg})$, milk protein $(\mathrm{kg})$, milk volume $(\mathrm{L})$, body weight $(\mathrm{kg})$, survival (\%), residual survival (\%), somatic cell count (cells/mL), fertility (\%), mammary system [Australian Breeding Value (ABV) unit], temperament (ABV unit), milking speed (ABV unit), udder depth (\%), overall type (\%), fore udder attachment (\%), and pin set (\%), respectively. The updated economic weights presented in this study constituted the basis of the definition for 3 new indices. These indices were developed from combination of bioeconomic principles, patterns of farmer preferences for trait improvements, and desired gains approaches. The 3 indices, Balanced Performance Index, Health Weighted Index, and Type Weighted Index, have been released to the industry.
\end{abstract}

Key words: economic value, selection index, dairy cattle, farmer preferences

\section{INTRODUCTION}

Economically efficient multiple-trait selection is usually achieved through the definition of breeding objec-

Received December 10, 2015.

Accepted June 3, 2016.

${ }^{1}$ Corresponding author: tbyrne@abacusbio.co.nz tives and the development of appropriate selection indices for specific production systems (James, 1980). The total genetic merit of an animal is frequently expressed in the form of an economic selection index, which uses the available information from the combination of an individuals' genetic merit and the breeding objective (James, 1980). Selection indices enable both breeders and commercial farmers to direct breeding emphasis toward specific market outcomes or address key production aspects of their particular farming system (Byrne et al., 2010).

In nations with well-structured dairy industries, an across-industry common breeding objective is often controlled at the national level (e.g., Veerkamp et al., 2002; Harris et al., 2007). The Australian Dairy Herd Improvement Scheme (ADHIS) is the institution in charge of the National Breeding Objective (NBO) implementation and monitoring. The aim of the NBO is to increase net farm profit; therefore, it must evolve over time in response to new knowledge and the demands of dairy businesses. Consequently, the NBO is reviewed on a regular basis to ensure that it remains relevant to the industry, and is supported by scientific and economic principles, as well as farmer's preferences. The first multitrait selection index released by ADHIS was in 1987 and included fat and protein yields. This was replaced by the Australian Selection Index in 1997 and Australian Profit Ranking (APR) index in 2001, which evolved to include 9 traits: milk volume, fat, and protein as well as survival, BW, SCC, fertility, milking speed, and temperament. In 2009, the assumptions and economic values of the APR were updated through the release of a new index, which deviated from strict economic values to include weights that had a component of desired gains (Pryce et al., 2009).

In the latest NBO review, which this study is part of, ADHIS put greater focus on obtaining direct input from farmers to support the scientific review of economic inputs and genetic parameters to be used in the construction and update of the breeding objective and selection index. The Australian Dairy Herd Improve- 
ment Scheme conducted a large-scale on-line survey of farmers' trait preferences, which revealed a desire to improve how traits were weighted and to review the range of traits to include in the updated NBO (MartinCollado et al., 2015).

The current study is the second stage of the NBO review, which comprises an update of the economic values (EV) for dairy traits for the Australian industry and the formulation of updated selection indices. This includes the reassessment of the economic parameters and calculation procedures, giving particular attention to farming system variation, and to the definition of additional selection indices based on results of the economic analysis, the outcomes of the farmer survey (Martin-Collado et al., 2015), and direct input by farmer consultation. Farmer consultation was conducted via a NBO review task force group, consisting of a selected group of farmers and industry representatives charged with delivering the best outcome for the Australian dairy industry.

\section{MATERIALS AND METHODS}

An economic model, which calculates partial economic values for each trait individually, was developed to determine the economic implications of selective dairy breeding, based on the effect of trait changes on the profit of commercial dairy farms in Australia. The formulation of the new NBO included 8 of the 9 traits considered in the previous NBO (as previously mentioned) plus 3 additional traits (mammary system, overall type, and feed saved). Feed saved has partially replaced BW, as it is a combination of residual feed intake and feed required for maintenance predicted from BW (Pryce et al., 2015). This additional set of traits was included in response to an industry consultation process carried out as the first stage of the ADHIS NBO review (Martin-Collado et al., 2015). The bioeconomic model computed industry-average production performance, taking into account farming system variation, to determine the $\mathrm{EV}$ of profit traits used to establish selection indices. The model can be divided into the following 3 stages.

(1) Calculation of economic values: Input cost variables and revenue streams were computed to determine the EV of each dairy trait. The EV of a trait is the marginal value of 1 unit change in the respective trait.

(2) Derivation of economic weights: Selection indices were developed from EV, which were transformed into base economic weights (EW) by including the discounted genetic expression (DGE) coefficients. Discounted genetic expression coefficients account for the different rates and timing of expression of the genetic superiority for the trait over a planning horizon in the progeny of the selection candidates (Hill, 1974; Amer, 1999). In some cases, base EW were in turn multiplied by genetic regressions, which account for the effect of specific trait changes on other trait changes, and conversion factors used to standardize differences in units of trait expressions, to get the final EW of each trait.

(3) Development of selection indices: Once the final EW of traits were calculated, different selection indices were developed. For several of the selection indices, a desired gains approach was used to align trait economic weightings to patterns of farmer preference revealed in the farmer survey and in consultation with the NBO review task force.

The specific calculations described in the following 3 sections correspond to each of the stages above. The results of each stage, which are presented at the end of each section, inform the calculation of the subsequent stage.

\section{Calculation of EV}

This section presents the calculations of EV for all dairy traits included in the Australian NBO review. All the equations used to calculate EV are described in detail in each specific trait subsection. Equations are presented with 2 kinds of parameters: (a) input parameters (always in lowercase), and (b) intermediate parameters derived from calculations in intermediate equations (always in capital letters). Some trait EV (e.g., the economic values for BW and fertility) consist of different components. These components were calculated discretely because for BW, for example, some are expressed by cows (cow maintenance weight) and some by replacements (replacement heifer costs); this requires an account of differences in timing and frequency of expressions of each component in the herd when the EW is expressed per cow per lactation. Then, components were aggregated, with inclusion of the respective DGE coefficients, together to comprise the overall trait EW. For clarity, input parameters and assumptions are presented either in the trait EV description or in the Appendix.

EV of Milk Production Traits. Three milk production traits were included in the breeding objective: protein yield $(\mathrm{kg})$, fat yield $(\mathrm{kg})$, and milk volume $(\mathrm{L})$, which were calculated under a milk solids payment scenario and under a volume of milk payment scenario. 
Key Assumptions. Calculation of milk production trait EV were based on 2 key input parameters: milk volume charge $(\mathrm{mvc})$ and milk solids price $\left(\mathrm{msp}_{\$}\right)$. Milk volume charge is the transport charge applied per liter of milk at the farm gate $[\mathrm{A} \$ / \mathrm{L}$ (Table A1)]. Conversely, industry figures for milk solids price were adjusted to account for an embedded volume penalty to account for shipping and processing costs. The adjusted milk solids price (AMSP) was calculated as

$$
\mathrm{AMSP}=\operatorname{msp}_{\$}+\mathrm{MSA},
$$

where $\operatorname{msp}_{\$}$ is the milk revenue per kilogram of milk solids at the farm gate (Table A1). Here, MSA is the adjusting term that accounts for the milk volume charge on a per kilogram of milk solids basis, calculated as

$$
\mathrm{MSA}=\frac{\mathrm{mvc}}{\frac{\operatorname{prot} \%+\text { fat } \%}{100}},
$$

where prot $\%$ and fat $\%$ are the percent protein and fat in milk, respectively (Table A1).

$\boldsymbol{E} \boldsymbol{V}$ Calculation. The EV of milk volume under a milk solids payment scenario $\left(\mathrm{EV}_{\text {Vol-Solids }}\right)$ was equal to the milk volume charge (mvc). The EV for milk volume, under the payment scenario per liter of milk, was calculated as

$$
\begin{gathered}
\mathrm{EV}_{\text {Vol-Liters }}=\text { milk.price }_{\text {Liters }}-\text { lact } \% \times \mathrm{L}_{\text {addit.feed }} \\
-\operatorname{prot} \% \times \mathrm{P}_{\text {addit.feed }}-\text { fat } \% \times \mathrm{F}_{\text {addit.feed }},
\end{gathered}
$$

where milk.price Liters $_{\text {is }}$ is the milk price per liter, lact\% is the percentage of lactose in milk (Table A1), and $\mathrm{L}_{\text {addit.feed }}$, $\mathrm{P}_{\text {addit.feed }}$, and $\mathrm{F}_{\text {addit.feed }}$ is the feed cost associated with $1 \mathrm{~kg}$ of lactose, protein, and fat, respectively. These feed costs were calculated as the average purchased feed price $\left(\mathrm{FC}_{\S}\right.$, see below) multiplied by the feed energy requirements to produce either a $\mathrm{kg}$ of lactose (feed.lact), fat (feed.fat), or protein (feed.prot; Table A1).

The EV of protein and fat were calculated as

$$
\mathrm{EV}_{\text {Prot }}=\mathrm{A}_{\text {Prot }}-\mathrm{P}_{\text {addit.feed }},
$$

and

$$
\mathrm{EV}_{\mathrm{Fat}}=\mathrm{A}_{\text {Fat }}-\mathrm{F}_{\text {addit.feed }},
$$

where $A_{\text {Prot }}$ and $A_{\text {Fat }}$ are the farm gate values of protein and fat adjusted for volume charge, calculated based on their relationship with AMSP (equation 1) as

$$
\operatorname{AMSP}=\left(\mathrm{A}_{\text {Prot }} \times \mathrm{P}_{\mathrm{MSR}}\right)+\left(\mathrm{A}_{\mathrm{Fat}} \times \mathrm{F}_{\mathrm{MSR}}\right),
$$

where $\mathrm{P}_{\mathrm{MSR}}$ is the ratio of protein to total milk solids $[\operatorname{prot} \% /(\operatorname{prot} \%+$ fat $\%)]$ and $\mathrm{F}_{\mathrm{MSR}}$ is the ratio of fat to total milk solids.

The rearrangement of equation 6 gives $A_{\text {Prot }}$ as a function of AMSP, where the ratios of milk components to milk solids and fat and protein prices were calculated as

$$
\mathrm{A}_{\text {Prot }}=\frac{\mathrm{AMSP}}{\mathrm{P}_{\mathrm{MSR}}+\left(\frac{\mathrm{fat}_{\$}}{\operatorname{prot}_{\$}} \times \mathrm{F}_{\mathrm{MSR}}\right)},
$$

and

$$
\mathrm{A}_{\mathrm{Fat}}=\frac{\mathrm{fat}_{\$}}{\operatorname{prot}_{\$}} \times \mathrm{A}_{\text {Prot }},
$$

where fat $_{\$}$ and $\operatorname{prot}_{\$}$ are the milk fat and milk protein price at farm gate (Table A1).

Milk component market prices are heavily influenced by international market conditions and prices (Dairy Australia, 2013a). Medium-term milk price averages were used to minimize the effect of milk price volatility. Milk price parameters (milk.price ${ }_{\text {Liters }}, \operatorname{mvc}, \operatorname{prot}_{\$}$, fat $_{\$}$ ) were averaged across 4- or 5-yr historic market prices (depending on data available) plus a 1-yr forecast and weighted across Australian regions (Table A1).

Calculation of Feed Cost Assumptions. Average feed cost in Australia ( $\mathrm{A} \$ / \mathrm{MJ}$ of $\mathrm{ME}$ ) was calculated as the weighted average feed costs across Australian regions as

$$
\mathrm{FC}_{\$}=\frac{\sum\left(\mathrm{PRICE}_{\mathrm{j}}^{\text {feed }} \cdot \mathrm{n}_{\mathrm{j}}^{\text {cows }}\right)}{\sum \mathrm{n}_{\mathrm{j}}^{\text {cows }}},
$$

where $\mathrm{PRICE}^{\text {feed }}(\mathrm{A} \$ / \mathrm{MJ}$ of $\mathrm{ME})$ is the average purchase price of feed and $n_{j}^{\text {cows }}$ is the number of dairy cows in the Australian region $\mathrm{j}$. The $\mathrm{PRICE}^{\text {feed }}$ in each region $\mathrm{j}$ was calculated as

$$
\text { PRICE }_{j}^{\text {feed }}=\frac{\text { price }_{j}^{\text {feed }}}{\text { energy }_{j}^{\text {feed }}},
$$

where PRICE $\mathrm{j}_{j}^{\text {feed }}$ is the average price or purchased feed in $\mathrm{j}$ region and energy $\mathrm{y}_{\mathrm{j}}^{\text {feed }}$ is the average energy content in megajoules of ME per kilogram of feed in region $j$ (Table A1). The PRICE $\mathrm{j}_{\mathrm{j}}^{\text {feed }}$ was calculated as a weighted average of prices of different feed categories (concen- 
Table 1. Inputs for the calculation of differences in cull cow revenue for a herd with survival improved by $1 \%$ versus the base herd ${ }^{1}$

\begin{tabular}{|c|c|c|c|c|c|c|c|c|c|c|}
\hline Lactation & $\begin{array}{c}\text { LWT, } \\
\text { kg }\end{array}$ & $\underset{\%}{\mathrm{DF}}$, & \multicolumn{4}{|c|}{ Base herd } & \multicolumn{4}{|c|}{ Base $+1 \%$ herd $^{2}$} \\
\hline 1 & 488 & 5 & 0.809 & 22.5 & 19 & 18 & 0.819 & 21.9 & 18 & 17 \\
\hline 3 & 624 & 10 & 0.922 & 15.0 & 5 & 5 & 0.932 & 15.0 & 5 & 4 \\
\hline 4 & 641 & 10 & 0.780 & 13.8 & 14 & 12 & 0.788 & 13.9 & 13 & 12 \\
\hline 5 & 650 & 10 & 0.694 & 10.8 & 15 & 13 & 0.699 & 11.0 & 15 & 14 \\
\hline 8 & 653 & 30 & 0.616 & 3.3 & 6 & 4 & 0.621 & 3.5 & 6 & 4 \\
\hline 9 & 653 & 30 & 0.616 & 2.1 & 4 & 2 & 0.621 & 2.2 & 4 & 3 \\
\hline 10 & 653 & 30 & 0.000 & 1.4 & 6 & 4 & 0.000 & 1.3 & 6 & 4 \\
\hline
\end{tabular}

${ }^{1} \mathrm{LWT}=$ cow body weight by lactation, $\mathrm{DF}=$ percentage of cows dying on farm from lactation $\mathrm{j}$ to $\mathrm{j}+1$, SR $=$ industry average survival rates, lact $\%=$ milking herd age distribution by lactation, $d=$ percentage of cows exiting the herd from lactation $j$ to $j+1$, ds $=$ percentage of cows salvaged over those exiting the herd from lactation $\mathrm{j}$ to $\mathrm{j}+1$.

${ }^{2}$ Survival-improved herds are modeled to have the survival rates in the first 3 parities increased by $1 \%$.

trate, silage, hay, and other feed) averaged for the last $5 \mathrm{yr}$ to account for price volatility (Table A1).

$\boldsymbol{E} \boldsymbol{V}$ of Survival. The EV of survival was defined as the expected increase in herd profit resulting from a $1 \%$ change in herd survival. Improving survival affects herd profitability in 2 ways. First, more profit is available from older cows because of higher milk production (when compared with first-lactation cows) and lower nonfeed costs (e.g., less calving difficulty and rebreeding), even after accounting for higher costs associated with mastitis treatment and lower average genetic merit. Second, fewer replacements are required, therefore reducing replacement costs. The marginal increase in herd profit was calculated by comparing the above components for a herd with average industry survival rates (Base ${ }^{\text {Surv }}$ ) and a herd with improved survival rates $\left(\right.$ Base $\left.^{\text {Surv }+1 \%}\right)$. Survival rates were modeled through variation in the proportion of cows surviving in each lactation between the 2 herds (Table 1). Specifically, the EV of survival was calculated as

$$
\mathrm{EV}_{\text {Survival }}=\sum_{l=1}^{10}\left[\left(\mathrm{I}_{1}^{+1 \%}-\mathrm{Rcost}_{1}^{+1 \%}\right)-\left(\mathrm{I}_{1}^{\mathrm{Ave}}-\mathrm{Rcost}_{1}^{\mathrm{Ave}}\right)\right] \text {, }
$$

where $\mathrm{I}_{1}^{\mathrm{Ave}}$ and $\mathrm{I}_{1}^{+1 \%}$ are the revenues per cow exiting the herd in lactation 1 in Base ${ }^{\text {Surv }}$ and Base ${ }^{\text {Surv }+1 \%}$ herds, respectively, and $\mathrm{Rcost}_{1}^{\mathrm{Ave}}$ and $\mathrm{R}_{\mathrm{cost}} \mathrm{H}^{+1 \%}$ are the replacement heifer costs. Replacement costs in each lactation were calculated as the direct heifer replacement cost in lactation 1 multiplied by the proportion of cows in each lactation group (lact ${ }_{1}^{\%}$; Table 1). Replacement costs per cow exiting differ between lactations because, per lactating cow in the herd, the cost to replace a young cow is much more than the cost to replace an older cow. This is because the older cows will have lower expected remaining herd life and, therefore, their loss from the herd has a lower effect on equilibrium herd age structure and replacement rate (Amer et al., 2001).

Revenue per cow exiting the herd in each lactation $\left(\mathrm{I}_{1}\right)$ was calculated as the percentage of salvaged cows (culled and slaughtered) over the cows exiting the herd in lactation 1 ( $\mathrm{ds}_{1}$; Table 1$)$ multiplied by the average cull cow salvage value. The average cull cow salvage value $(\mathrm{CSV})$ was calculated as

$$
\mathrm{CSV}=\sum_{l=1}^{10}\left(\frac{\mathrm{CSV}_{\mathrm{l}} \times \mathrm{lact}_{1}^{\%}}{\text { lact }_{1}^{\%}}\right) .
$$

The average cull cow salvage value in each lactation 1 was calculated as:

$$
\mathrm{CSV}_{1}=\mathrm{lwt}_{1} \times \mathrm{cwt}_{\$} \times \mathrm{dp}_{\%},
$$

where $\mathrm{lwt}_{1}$ is the average cow $\mathrm{BW}$ in lactation $\mathrm{l}$, $\mathrm{cwt}_{\$}$ the cull cow carcass price, and $\mathrm{dp}_{\%}$ the cull cow dressing percentage (Table A1).

Higher Profit of Older Cows. Table 2 presents the profit per lactation for cows in the different lactations. The numbers result from milk production (after adjustment for feed costs associated with milk component production), calving costs, genetic trend (whereby older cows are of lower genetic merit than younger cows, assuming selection under the previous index, generating progress of $\mathrm{A} \$ 7.54 \mathrm{APR}$ units per year (G. Nieuwhof, ADHIS, Melbourne, Australia, personal communication), costs associated with mastitis and lameness, as well as differences in feed costs 
for growth of heifers and maintenance of older cows. The average progress in merit was based on national genetic trends of cows sired by National AB Sire Identification Scheme (NASIS) and non-NASIS bulls between the period of 1990 and 2012 (J. E. Pryce, personal communication). The reason for including the genetic trend effect is because a disadvantage of having lower herd turnover (i.e., higher survival) is that the average genetic merit and performance of the herd is lower due to the average cow age being older and those older cows are of lower genetic merit relative to younger cows. Double counting is avoided here because this genetic trend effect is based on changes in the age structure of the herd with changing survival, rather than changes in other traits in the index with changing survival.

Lower Replacement Rate. Further account has been made for the lower replacement rate associated with the higher (Base ${ }^{\text {Surv }+1 \%}$ ) survival herd. At a cost of $\mathrm{A} \$ 1,606$ per replacement heifer $\left(\mathrm{H}_{\text {Cost }}\right)$, the average replacement cost expressed per cow in the herd, for the Base $^{\text {Surv }}$ and Base ${ }^{\text {Surv }+1 \%}$ survival herds were $\mathrm{A} \$ 408$ and $\mathrm{A} \$ 420$, respectively. The cost of a replacement heifer was calculated as the average price of a young dairy cow for the domestic and the export market. An adjustment factor was used to account for the opportunity cost of selling an improved heifer in a demanding export market, assuming historic average prices (Dairy Australia, 2013b; MLA, 2014). The comparison of profit per lactation in different parities between the base herd and the herd with improved survival rates is presented in Table 3.

$\boldsymbol{E} \boldsymbol{V}$ of $\boldsymbol{B} \boldsymbol{W}$. Changes in cow BW are expected to result in changes in (1) feed requirements for the maintenance of larger cows, (2) feed requirements for maintaining and growing larger replacements, (3) cow cull value, and (4) bobby calf (i.e., calves sent for slaughter) weight. The EV of the 4 BW components were calculated separately by comparing an average industry herd $\left(\right.$ Base $\left.^{\mathrm{BW}}\right)$ with a herd with an average cow BW $1 \mathrm{~kg}$ higher than the base herd (Base ${ }^{\mathrm{BW}+1 \mathrm{~kg}}$ ).

Cow Maintenance Component. The EV of cow maintenance requirements $\left(\mathrm{EV}_{\mathrm{BW}}^{\mathrm{Maint}}\right)$ was calculated as the total feed costs of maintenance for a Base ${ }^{\mathrm{BW}}$ herd $\left(\mathrm{FEED}_{\$ \text { cost }}^{\text {Maint.base }}\right)$ compared with the $\mathrm{FEED}_{\$ \text { कcost }}^{\text {Maint }+1 \mathrm{~kg}}$ in a Base $^{\mathrm{BW}+1 \mathrm{~kg}}$ herd. Feed costs of maintenance were calculated as the total energy requirements for maintenance, either in a Base $^{\mathrm{BW}}$ or in a Base ${ }^{\mathrm{BW}+1 \mathrm{~kg}}$ herd, multiplied by the $\mathrm{FC}_{\$}$ (equation 9 ). Total energy requirements for maintenance $\left(\mathrm{ER}^{\text {Maint }}\right)$ were calculated assuming different average requirements between the 3 main breed groups, Holstein, Jersey, and other breeds, and the weighted average final component was computed as

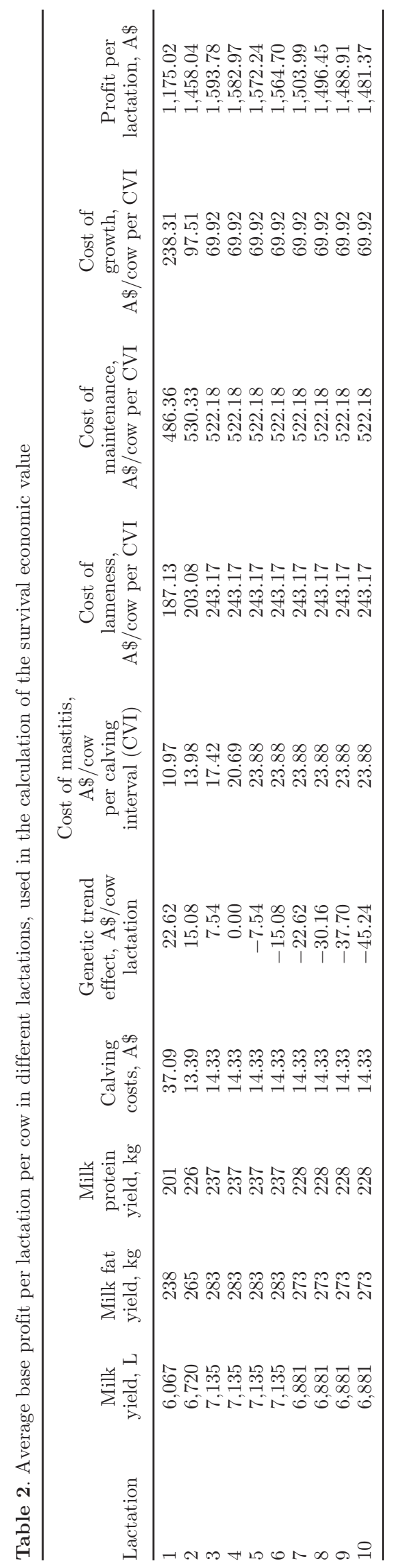


Table 3. Aggregation of profit per cow per lactation (PPL) in different lactations used to generate the final economic value of survival

\begin{tabular}{lccc}
\hline Lactation & $\begin{array}{c}\text { Aggregated } \\
\text { PPL, A } \$\end{array}$ & $\begin{array}{c}\text { Base } \\
\text { PPL }^{1} \text { A } \$\end{array}$ & $\begin{array}{c}\text { Base }^{+1 \%} \\
\text { PPL }^{1}{ }^{1} \mathrm{~A} \$\end{array}$ \\
\hline 1 & 1,175 & 265 & 257 \\
2 & 1,458 & 266 & 261 \\
3 & 1,594 & 239 & 238 \\
4 & 1,583 & 219 & 221 \\
5 & 1,572 & 170 & 173 \\
6 & 1,565 & 117 & 120 \\
7 & 1,504 & 82 & 84 \\
8 & 1,496 & 50 & 52 \\
9 & 1,489 & 31 & 32 \\
10 & 1,481 & 19 & 20 \\
Total & - & 1,457 & 1,459 \\
\hline
\end{tabular}

${ }^{1}$ Expressed as the contribution by cow age cohort per lactating cow per lactation in the herd.

$$
\mathrm{ER}^{\text {Maint }}=\sum_{\mathrm{b}=1}^{3} \frac{\text { energ.req }}{\mathrm{b}_{\mathrm{b}}^{\text {Maint }} \times \mathrm{n}_{\mathrm{b}}},
$$

where energy.req ${ }^{\text {Maint }}$ is the average maintenance energy requirements across cow age periods per kilogram of BW (Table 4) and $n_{b}$ the number of cows of the different breeds (Table A1).

Heifer Replacement Feed Cost Component. The EV of the heifer replacement feed cost component $\left(\mathrm{EV}_{\mathrm{BW}}^{\text {Growth }}\right)$ was calculated as the total feed costs of growth $\left(\mathrm{FEED}_{\$ \text { cost }}^{\text {Growth.base }}\right)$ in a Base $^{\mathrm{BW}}$ herd, compared with the $\mathrm{FEED}_{\$ \text { cost }}^{\text {Growth }} \mathrm{kg}$ in a Base ${ }^{\mathrm{BW}+1 \mathrm{~kg}}$ herd. Feed costs of growth were calculated as the product of the $\mathrm{FC}_{\$}$ (equation 9) and the total feed requirements for growth (energy.req ${ }^{\text {Growth }}$ ) in Base ${ }^{\mathrm{BW}}$ or Base ${ }^{\mathrm{BW}+1 \mathrm{~kg}}$ herds weighted across breeds (Table A2).
Cow Cull Carcass Component. The EV of the cull cow component $\left(\mathrm{EV}_{\mathrm{BW}}^{\mathrm{Cull}}\right)$ accounted for the higher salvage value of slaughtered cull cows in a Base ${ }^{\mathrm{BW}+1 \mathrm{~kg}}$ herd compared with the Base ${ }^{\mathrm{BW}}$ herd. Cows dying before culling, as opposed to those slaughtered as cull cows, were taken into account in the calculation of the appropriate DGE coefficient, as described in the DGE section. Specifically, the EV of the cull cow component of BW was calculated as the average revenue, or carcass value, per cow culled, weighted across breeds in a Base $^{\mathrm{BW}+1 \mathrm{~kg}}$ herd $\left(\mathrm{I}_{\$}^{\mathrm{Cull}+1 \mathrm{~kg}}\right)$ compared with $\mathrm{I}_{\$}^{\text {Cull.base }}$ in a Base $^{\mathrm{BW}}$ herd. Average revenue per cow culled was calculated as:

$$
\mathrm{I}_{\$}^{\text {Cull }}=\overline{\mathrm{CW}_{\$}} \times \overline{\mathrm{CW}}
$$

where $\overline{\mathrm{CW}_{\$}}$ is the average carcass price per kilogram after accounting for the proportions of carcasses in different price bands in the different breeds and $\mathrm{CW}$ is the average carcass weight across breeds. The average carcass value was calculated as

$$
\overline{\mathrm{CW}}_{\$}=\sum_{\mathrm{b}=1}^{3} \sum_{\mathrm{i}=1}^{3} \rho_{\mathrm{bi}} \times \mathrm{V}_{\mathrm{i}} \times \mathrm{CW}_{\mathrm{i}}
$$

where $\mathrm{V}_{\mathrm{i}}$ is the average price per kilogram in the ith band (Table 5), $\rho_{\mathrm{bi}}$ is the proportion of carcasses in the ith carcass price band per breed b, and $\mathrm{CW}$ is the average carcass weight in each ith band (Table 6). The proportion of carcasses in each ith price bands was calculated as

Table 4. Across-breed average energy requirements for maintenance by cow age period in an average industry herd $\left(\right.$ Base $\left.^{\mathrm{LWT}}\right)$ and in the herd with a 1-kg increase in average cow BW (Base ${ }^{\mathrm{LWT}+1 \mathrm{~kg}}$ )

\begin{tabular}{lrr}
\hline & \multicolumn{2}{c}{$\begin{array}{c}\text { Energy requirements, } \\
\text { MJ of ME }\end{array}$} \\
\cline { 2 - 3 } Cow age period & Base ${ }^{\text {LWT }}$ & Base $^{\text {LWT+1 kg }}$ \\
\hline Female slaughter calves (birth to slaughter age), 1st period & 37 \\
Female calves (slaughter age to weaning), 2nd period & 724 \\
Female calves (weaning to change in grazing costs), 3rd period & 4,893 \\
Female calves (change in grazing costs to 12 mo), 4th period & 3,051 & 4,901 \\
Female calves (12 mo to mating age), 5th period & 3,456 & 3,055 \\
Female calves (mating age to 1st parturition), 6th period & 13,269 & 3,460 \\
Heifers (total up to 1st parturition) & 25,430 & 25,467 \\
Heifers (1st parturition to 2nd parturition) & 19,656 & 19,684 \\
Cows (2nd parturition to 3rd parturition) & 21,433 & 21,459 \\
Cows (3rd and further lactations) & 21,104 & 21,129 \\
Across-breed ${ }^{2}$ energy.req ${ }^{\text {Maint }}$ & 25,756 & 25,790 \\
\hline
\end{tabular}

${ }^{1}$ Calculated for industry average mature cow BW weighted across breeds: 628, 486, and $562 \mathrm{~kg}$ for HolsteinFriesian, Jersey, and cross-breed cows, respectively. Haile-Mariam et al. (2014).

${ }^{2}$ Weighted average maintenance energy requirements of cows in the different lactations. 
Table 5. Average historical cow carcass price $(\mathrm{A} \$ / \mathrm{kg})$ across carcass bands in Australia ${ }^{1,2}$

\begin{tabular}{lccc}
\hline Year & $\begin{array}{c}\text { Carcass band 1, } \\
\text { BW 1-400 kg }\end{array}$ & $\begin{array}{c}\text { Band 2, } \\
\text { BW 401-520 kg }\end{array}$ & $\begin{array}{c}\text { Band 3, } \\
\text { BW } \geq 521 \mathrm{~kg}\end{array}$ \\
\hline 2009 & 2.33 & 2.51 & 2.61 \\
2010 & 2.59 & 2.73 & 2.83 \\
2011 & 2.79 & 2.93 & 3.05 \\
2012 & 2.42 & 2.63 & 2.76 \\
2013 & 2.09 & 2.32 & 2.51 \\
2014 & 2.11 & 2.46 & 2.61 \\
Average price, $V_{i}$ & 2.44 & 2.61 & 2.76 \\
\hline
\end{tabular}

${ }^{1}$ Consumer price index adjusted.

${ }^{2}$ MLA Dairy Cows Prices 5 yr (Damon Holmes, Meat and Livestock Australia, Sydney, Australia, personal communication).

$$
\rho_{\mathrm{i}}=\int_{\mathrm{lb}_{\mathrm{i}}}^{\mathrm{ub}_{\mathrm{i}}} \mathrm{N}\left(\mathrm{x}, \mathrm{CW}_{\mathrm{b}}, \sigma_{\mathrm{cw}}\right) \cdot \mathrm{c}_{\mathrm{dx}},
$$

where $\mathrm{ub}_{\mathrm{i}}$ and $\mathrm{lb}_{\mathrm{i}}$ are the upper and lower carcass weights in band i. Carcass weights were assumed to have a normal distribution density function with mean carcass weight equal to $\mathrm{CW}_{\mathrm{b}}$ and standard deviation of $\sigma_{\mathrm{cw}}$, where $\mathrm{c}_{\mathrm{dx}}$ is the within-breed coefficient of variation for cull cow carcass weight of $15 \%$.

Lighter cows have a lower price per kilogram of carcass; thus, an increase in cow BW can lift carcass returns through both a higher price per kilogram of carcass and through heavier carcasses (Table 5). This change in price (per kilogram of carcass) is captured by assuming an underlying normal distribution of cull cow carcass weight and predicting the proportions of carcasses in each category (by breed), by computing the area under the normal distribution curve between thresholds delineating groups (equation 17). We modeled the genetic change in cow BW assuming that the underlying normal distribution moves in relation to the thresholds. In this way, the changes in proportions of animals in different weight and price bands with a genetic change in cow BW could be predicted (Table 6).

The average carcass values (equation 16) of a cull cow carcass for each breed were calculated at $\mathrm{A} \$ 961$,
$\mathrm{A} \$ 718$, and $\mathrm{A} \$ 852$ and $\mathrm{A} \$ 977, \mathrm{~A} \$ 736$, and $\mathrm{A} \$ 869$ for Friesians, Jerseys, and crossbreds, respectively, at the base mature BW herd scenario and for the $10 \mathrm{~kg}$ heavier BW scenario.

Bobby Calf Value Component. The EV of the bobby calf value (i.e., slaughter calf value) was calculated as

$$
\mathrm{EV}_{\mathrm{BW}}^{\text {Bobby }}=\mathrm{v}_{\text {Bobby }} \times \mathrm{b}_{\mathrm{lwt}_{\text {Bobby }}, \mathrm{lwt} \text { cow }},
$$

where $\mathrm{v}_{\text {Bobby }}$ is the average slaughter calf price, and $\mathrm{b}_{\mathrm{lwt}_{\text {Bobby }}, \mathrm{lwt}_{\text {cow }}}$ is the genetic regression of slaughter calf live weight on cow BW (equation 44; Table A3). Therefore, a $0.078-\mathrm{kg}$ increase in slaughter calf live weight per kilogram of increase in cow BW and a dressing of $53.7 \%$ was used. Slaughter calf price $\left(\mathrm{v}_{\text {Bobby }}\right)$ was obtained from consultation with industry stakeholders and based on policies for calves born and sold to finishers as bobby calves. Heavier calves were assumed to receive a $\mathrm{A} \$ 1.00$ premium per kilogram of $\mathrm{BW}$. The effect of calving difficulty in the EV of bobby calf value is not accounted for because no data is currently available on the correlation between cow size and calving difficulty in Australia. We would not expect calving difficulty to increase, with larger cow size, because both the cow and the calf would be getting larger.

Table 6. Average carcass weights (CWT) and proportions of cull cows across band prices by breed

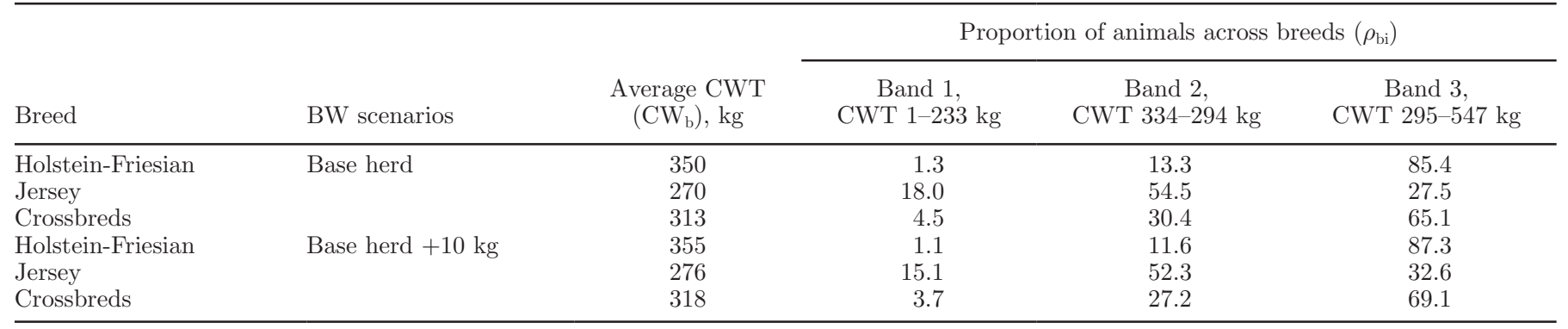


EV $\boldsymbol{V}$ of Feed Saved. In April 2015, ADHIS released feed-saved Australian breeding values (ABV) to the industry, which are used for selecting cows that have actual feed intake less than predicted for their level of production and lower predicted maintenance requirements (Pryce et al., 2015). In Holstein genotyped animals, feed saved includes maintenance feed requirements (predicted from the ABV for BW) plus genomic breeding values for residual feed intake (RFI), where RFI is the difference between actual and predicted feed intake. Residual feed intake was calculated using a genomic reference population of lactating cows (from Australia, United Kingdom, and the Netherlands) and growing heifers (from Australia) in a multitrait analysis where the traits were RFI in lactating Australian and European cows and Australian growing heifers. The output of the analysis is 3 genomic prediction equations. These prediction equations are applied to Holstein genotypes (for animals without phenotypes), and RFI genomic breeding values for growing heifers and Australian lactating cows are combined to produce a genomic breeding value of an (approximate) annualized expression of RFI that covers both the growth and lactation stages of life. The final step is to subtract RFI from the amount of feed required for maintenance per year inferred from BW ABV; this gives the feed-saved ABV. In other breeds and animals without a genotype, feed saved only includes the ABV for maintenance feed requirements (predicted from BW; Pryce et al., 2015). Feed saved replaces BW in selection indices, the EW is expressed as kilograms of feed saved per year, and its $\mathrm{EV}$ is calculated using the maintenance component of the economic value of BW described herein. Predicted responses to selection in our paper are modeled for the feed saved trait.

Pryce et al. (2015) describes the calculation of feed saved in detail, including the conversion of the ABV and EW from the maintenance component of the economic value of BW to feed saved [equation 7 in Pryce et al. (2015)].

$\boldsymbol{E} \boldsymbol{V}$ of $\boldsymbol{S C C}$. The calculation of the EV of SCC is complex because it is nonlinear: an increase in SCC pushes more milk into the penalized milk SCC quality class when compared with the amount of milk that goes into the premium classes when SCC is reduced. The EV of SCC also includes a clinical mastitis component that accounts for a change in SCC as an indicator of mastitis. Therefore, the EV of SCC was calculated as the average differences in penalty or premiums applied to milk prices when SCC increases or decreases plus the genetic regression of clinical mastitis incidence on SCC, as

$$
\mathrm{EV}_{\mathrm{SCC}}=\frac{\mathrm{EV}_{\mathrm{SCC}}^{\mathrm{up}}+\mathrm{EV}_{\mathrm{SCC}}^{\mathrm{down}}}{2}+\mathrm{EV}_{\text {Mastitis }} \cdot \mathrm{b}_{\text {Mastitis/SCC }} \text {, }
$$

where $\mathrm{EV}_{\mathrm{SCC}}$ is the economic value of a unit change in SCC ABV (either upward or downward), which was calculated as the change in income $\left(\Delta \mathrm{I}_{\S}^{\mathrm{SCC}}\right)$ per change in SCC ABV required for a 50,000-cell change in SCC score $\left(\Delta \mathrm{scc}_{\mathrm{BV}}\right.$; Table $\left.\mathrm{A} 1\right) ; \mathrm{EV}_{\text {Mastitis }}$ is the economic value of mastitis (equation 39), which accounts for the cost of one case of clinical mastitis ( $-\mathrm{A} \$ 106.20)$; and $\mathrm{b}_{\text {Mastitis/SCC }}$ is the genetic regression of the incidence mastitis on SCC (equation 44; Table A3). Thus,

$$
\mathrm{EV}_{\mathrm{SCC}}^{\mathrm{j}}=\frac{\Delta \mathrm{I}_{\mathrm{Sscc}}}{\Delta \mathrm{scc}_{\mathrm{BV}}}
$$

The change in income from a 50,000-cell change in SCC in the whole lactation was calculated as

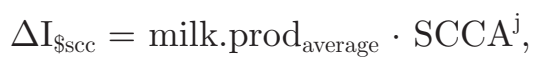

where milk.prod $_{\text {average }}$ is the average cow milk production per lactation in liters (Table A1) and $\mathrm{SCCA}^{\mathrm{j}}$ is the total economic effect per liter from the SCC BV change, associated with a 50,000-cell change upward or downward count. The change was calculated as

$$
\mathrm{SCCA}^{\mathrm{j}}=\overline{\mathrm{V}}^{\mathrm{j}}-\overline{\mathrm{V}}^{\text {current }},
$$

where $\overline{\mathrm{V}}^{\mathrm{j}}$ is the penalty or bonus per liter when SCC increases or decrease (Table 7 ), which was calculated as

$$
\overline{\mathrm{V}}^{\mathrm{j}}=\sum \frac{\mathrm{V}_{\mathrm{SCC}}^{\mathrm{i}} \times \rho_{\mathrm{SCC}}^{\mathrm{i}}}{\sum \rho_{\mathrm{SCC}}^{\mathrm{i}}}-\mathrm{V}_{\mathrm{SCC}}^{\mathrm{t}},
$$

where $\mathrm{V}_{\mathrm{SCC}}^{\mathrm{i}}$ is the average penalty or bonus per liter in the ith SCC quality class (P1, P2, Base, 1st and 2nd grades; see Table 7), $\mathrm{V}_{\mathrm{SCC}}^{\mathrm{t}}$ is the penalty or bonus in threshold $\mathrm{t}$, and $\rho_{\mathrm{SCC}}^{\mathrm{i}}$ is the proportions of milk in each class. Specifically, $\rho_{\mathrm{SCC}}^{\mathrm{i}}$ was modeled as

$$
\rho_{\mathrm{SCC}}^{\mathrm{i}}=\int_{\operatorname{lscc}_{\mathrm{i}}}^{\mathrm{uscc}_{\mathrm{i}}} \mathrm{N}\left(\mathrm{x}, \overline{\mathrm{scc}}, \mathrm{sd}_{\mathrm{scc}}\right) \cdot \mathrm{uscc}_{\mathrm{dx}},
$$

where uscc $_{i}$ and $\operatorname{lscc}_{i}$ are the upper and lower SCC values in ith classes and $\mathrm{N}$ is the underlying normal distri- 
bution density function of SCC (mean $=\overline{\text { scc }}$ and standard deviation $=\mathrm{sd}_{\mathrm{scc}}$ ) and $\mathrm{uscc}_{\mathrm{dx}}$ is the coefficient of variation of SCC. The distribution parameters were defined based on a 10-d rolling average (Table 7).

$\boldsymbol{E} \boldsymbol{V}$ of Fertility. Changes in the average cow fertility results in changes in (1) cow survival, (2) rebreeding costs, (3) number of AI calves for sale or herd replacement, and (4) calving interval (especially in seasonal calving herds). The EV of these 4 components was calculated separately as follows.

Survival Component. The EV of the effects of fertility on survival was calculated as

$$
\mathrm{EV}_{\text {Fertility }}^{\text {Survial }}=\operatorname{surv}_{\$}^{\text {high }} \times\left(\rho_{\mathrm{cs}}^{\mathrm{SC}}+\rho_{\mathrm{cs}}^{\mathrm{Y}}\right)+\operatorname{surv}_{\$}^{\text {low }} \times \rho_{\mathrm{cs}}^{\mathrm{S}},[25]
$$

where $\operatorname{surv}_{\$}^{\text {high }}$ and surv ${ }_{\$}^{\text {low }}$ are the cost of replacement heifers per additional day in the calving interval (CVI) in herds with high or low milk production, and $\rho_{\mathrm{cs}}^{\mathrm{SC}}, \rho_{\mathrm{cs}}^{\mathrm{Y}}$, and $\rho_{\mathrm{cs}}^{\mathrm{S}}$ are the proportions of cows in split, year-round, and seasonal calving systems, respectively. The $\operatorname{surv}_{\$}^{\text {high }}$ and $\operatorname{surv}_{\$}^{\text {low }}$ were calculated as the genetic regression of survival on calving interval (equation 44) multiplied by the direct replacement heifer cost $\left(\mathrm{H}_{\text {Cost }}\right)$ of $\mathrm{A} \$ 1,606$ per replacement heifer, divided by 100 .

To create a standardized unit between fertility and survival, the genetic regression between both traits was multiplied by the EV of survival to give the survival component weighting to the overall fertility economic value. Table A3 presents the parameters used to derive the respective genetic regressions. Using standard formulae, the resulting values of genetic regressions of survival on calving interval were -0.1358 for high-CVI herds and -0.31113 for low-CVI herds. However, the published $\mathrm{ABV}$ of the fertility trait is not CVI, but pregnancy rate within $42 \mathrm{~d}$ of mating. The above coefficients were then divided by a conversion factor of -0.32 (G. Nieuwhof, ADHIS, Melbourne, Australia, personal communication) to get the regression of survival on pregnancy rate.

Rebreeding Costs Component. The EV of the rebreeding component was calculated by comparing the number of matings required in a herd with industry average fertility values (Base ${ }^{\text {Fert }}$ ) with those of a herd with a $1 \%$ increase of pregnancy rate within $42 \mathrm{~d}$ of mating $\left(\right.$ Base $\left.^{\mathrm{Fert}+1 \%}\right)$, as

$$
\mathrm{EV}_{\mathrm{Fertility}}^{\mathrm{AB}}=\frac{\Delta \mathrm{AI}_{\$}}{\Delta \mathrm{CR}_{42} \times 100}
$$

where $\Delta \mathrm{CR}_{42}$ is the difference in conception rate at 42 d (i.e., $1 \%$ ) between Base ${ }^{\text {Fert }}$ and Base ${ }^{\text {Fert+1\% }}$ herds, and $\Delta \mathrm{AI}_{\$}$ is the $\mathrm{AI}$ cost decrease after the $1 \% \mathrm{CR}_{42}$ increase. The parameters used to calculate AI costs are presented in Table A4. Note that, in Australia, AI is predominantly carried out by farmers rather than technicians. Therefore, AI rebreed costs are assumed to include only extra semen costs. This assumption was made in consultation with the NBO review task force.

Extra AI Calves Component. The EV of the extra AI calves component of fertility was calculated as

$$
\begin{aligned}
\mathrm{EV}_{\text {Fertility }}^{\text {ExtraB }}= & \Delta \mathrm{AB}_{\$}^{\text {dairy }} \cdot \operatorname{surp}_{\%}^{\text {heifer }} / 100 \\
& +\Delta \mathrm{AB}_{\$}^{\text {beef }} \cdot\left(100-\text { surp }_{\%}^{\text {heifer }}\right) / 100,
\end{aligned}
$$

where $\Delta \mathrm{AB}_{\oiint}^{\text {dairy }}$ and $\Delta \mathrm{AB}_{\Phi}^{\text {beef }}$ are the price differential of AI heifer relative to dairy- and beef-crossed animals, respectively, and $\operatorname{surp}_{\%}^{\text {heifer }}$ is the percentage of farmers producing surplus heifer calves (Table A1). The respective price differentials were calculated as

\begin{tabular}{|c|c|c|c|c|c|}
\hline \multirow[b]{2}{*}{ Parameter (acronym in the text) } & \multicolumn{5}{|c|}{ SCC quality classes } \\
\hline & $\mathrm{P} 1$ & $\mathrm{P} 2$ & Base & 1st grade & 2nd grade \\
\hline Proportion of milk $\left(\rho_{\mathrm{SCC}}{ }^{\mathrm{i}}\right)$. Current situation & 73.4 & 18.9 & 6.3 & 1.1 & 0.2 \\
\hline Proportion of milk $\left(\rho_{\mathrm{SCC}}\right)^{1}$. SCC 5,000 down & 82.5 & 12.1 & 5.0 & 0.5 & 0.0 \\
\hline Proportion of milk $\left(\rho_{\mathrm{SCC}}\right)$. SCC 5,000 above & 60.5 & 22.0 & 14.9 & 2.6 & 0.1 \\
\hline Price penalty/bonus $\left(\mathrm{V}_{\mathrm{SCC}} \mathrm{i}\right), \mathrm{A} \$ / \mathrm{L}$ & $0.038^{1}$ & $0.016^{1}$ & 0.000 & $-0.042^{2}$ & $-0.127^{2}$ \\
\hline
\end{tabular}

$$
\Delta \mathrm{AB}_{\$}^{\text {dairy }}=\frac{\left(1-\text { mort }_{\text {calf }}\right) \times \frac{1}{2} \Delta \mathrm{APR}_{\text {fert }}}{100},
$$

Table 7. Summary of parameter by SCC quality classes used to calculate the economic value of SCC

${ }^{1}$ Grades were based on $10-\mathrm{d}$ rolling average, on a premium of $\mathrm{A} \$ 0.18$ fat $/ \mathrm{kg}$ and $\mathrm{A} \$ 0.41$ protein $/ \mathrm{kg}$ for $\mathrm{P} 1$ and $\mathrm{A} \$ 0.08$ fat $/ \mathrm{kg}$ and $\mathrm{A} \$ 0.17 \mathrm{protein} /$ $\mathrm{kg}$ for P2 considering milk composition assumptions in Table A1.

${ }^{2} 10 \%$ discount of 1 st-grade milk and a $30 \%$ discount of 2 nd-grade milk applied to the milk price (Table A1). 
Table 8. Number of DIM, milk production, and milk yield in the last day of lactation across lactations and calving systems for cows with long and short calving intervals

\begin{tabular}{|c|c|c|c|c|c|}
\hline Variable (acronym) & Calving system & $\begin{array}{l}\text { Cow calving } \\
\text { interval length }\end{array}$ & Lactation 1 & Lactation 2 & Lactations $3-6$ \\
\hline \multirow[t]{3}{*}{$\overline{D I M}(\operatorname{dim}), \mathrm{d}$} & Split calving & Above average & 308.0 & 313.3 & 301.3 \\
\hline & \multirow{2}{*}{ All year calving } & Above average & 328.3 & 328.1 & 320.9 \\
\hline & & Below average & 284.2 & 282.5 & 270.2 \\
\hline \multirow{2}{*}{$\begin{array}{l}\text { Average total milk production } \\
\text { in a normal-length lactation herd } \\
\text { (prod.comp), L }\end{array}$} & \multirow[t]{2}{*}{ Split calving } & Above average & 6,911 & 8,135 & 8,521 \\
\hline & & Below average & 5,258 & 5,871 & 6,390 \\
\hline \multirow{4}{*}{$\begin{array}{l}\text { Milk yield in the last day in a } \\
\text { normal-length lactation herd, L }\end{array}$} & \multirow[t]{2}{*}{ Split calving } & Above average & 17.6 & 19.5 & 21.2 \\
\hline & & Below average & 14.1 & 14.6 & 16.3 \\
\hline & \multirow[t]{2}{*}{ All year calving } & Above average & 18.9 & 20.6 & 20.1 \\
\hline & & Below average & 16.2 & 17.2 & 18.5 \\
\hline
\end{tabular}

and

$$
\begin{aligned}
& \Delta \mathrm{AB}_{\$}^{\text {beef }}= \\
& \frac{\left(1-\text { mort }_{\text {calf }}\right) \times \frac{1}{2}\left[\left(\Delta \mathrm{AB}-\text { calf.female }_{\$}^{\text {beef }}\right)+\left(\text { calf.male }_{\$}^{\text {beef }}-\text { bobby }_{\$}\right)\right]}{100},
\end{aligned}
$$

where mort $_{\text {calf }}$ is the calf mortality, $\triangle A P R_{\text {fert }}$ is the average genetic merit (APR) differential of AI calves over natural mating calves, $\triangle \mathrm{AB}$ is the price differential of AI calves over natural mating calves, calf.female ${ }_{\$}^{\text {beef }}$ and calf.male ${ }_{\$}^{\text {beef }}$ are the prices of female and male calves sired by beef bulls, respectively, and bobby $_{\$}$ is the average slaughter calf value (Table A1). The calculation of $\triangle \mathrm{APR}_{\text {fert }}$ assumes that nonpregnant AI cows within $42 \mathrm{~d}$ of the start of the mating season will be mated naturally, leading to a reduction in the future value of these calves.

CVI Component. Records for CVI and milk production (extracted from ADHIS, 2013) were used to calculate the effect of fertility via changes in CVI. Records were partitioned for the calculation according to the following categorizations: (1) split-calving herds versus all-year calving herds and (2) below-average milk production cows (below-average CVI) versus aboveaverage production cows (above-average CVI). These patterns of milk production and CVI were the same as those observed by Haile-Mariam et al. (2013).

We defined the EV of lost milk resulting from an increase in CVI as the reduction in the overall potential milk yield due to the production drop in late lactation per extra CVI day, calculated as

$\mathrm{EV}_{\text {Fertility }}^{\text {Lostmilk }}=\frac{\sum_{\mathrm{i}=1}^{\mathrm{n}}\left(\Delta \operatorname{MilkComp}_{\mathrm{i}}^{\text {High }}\right)+\sum_{\mathrm{i}=1}^{\mathrm{n}}\left(\Delta \operatorname{MilkComp}_{\mathrm{i}}^{\text {Low }}\right)}{2}$, where $\mathrm{n}$ is the number of milk components, $\Delta \mathrm{MilkComp}_{\mathrm{i}}$ is the effect of change in ith milk component (milk volume, fat, and protein) production per extra CVI day in either a high- or a low-production herd in different calving systems (as per the categorizations above). This was calculated as

$$
\Delta \text { MilkComp }_{\mathrm{i}}=- \text { lact.length }_{\mathrm{l}} \times\left(\text { Drop }_{\mathrm{l}, \mathrm{i}} \times \rho_{\mathrm{l}}^{\text {lact }}\right) \times \mathrm{EV}_{\mathrm{i}},
$$

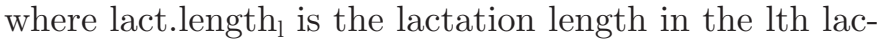
tation in either high- or low-production herds in different calving systems (Table 8), Drop l.i $_{\text {is }}$ the reduction in average production per day per cow of the ith milk component in the lth lactation with an extra CVI day, $\rho_{1}^{\text {lact }}$ is the proportion of cows in the lth lactation $\left(\rho_{1}^{\text {lact }}\right.$ first lactation $=22 \% ; \rho_{2}^{\text {lact }}$ second lactation $=18 \% ; \rho_{3}^{\text {lact }}$ third lactation and later $=60 \%$ ) and $\mathrm{EV}_{\mathrm{i}}$ is the $\mathrm{EV}$ of the ith milk component (as presented in the calculations of the EV of milk components).

We assumed that nonfeed costs were fixed irrespective of the stage of lactation. A herd with a higher proportion of cows in late lactation will have lower average milk production per cow per day compared with a herd of normal lactation length because production per day at the end of lactation is lower. Therefore, the drop in average production per day per cow for each milk component (i) in each lactation (1) with a 1-d extension in the CVI was calculated separately for either high- or low-production herds in different calving systems (as per the categorizations above), as

$$
\operatorname{Drop}_{\mathrm{s}, 1, \mathrm{i}}=\frac{\operatorname{prod} \cdot \operatorname{comp}_{\mathrm{s}, \mathrm{l}, \mathrm{i}}}{\operatorname{dim}_{\mathrm{s}, \mathrm{l}}}-\frac{\operatorname{prod}_{\mathrm{C}} \cdot \mathrm{comp}_{\mathrm{s}, \mathrm{l}, \mathrm{i}}^{\mathrm{CVI}+1}}{\operatorname{dim}_{\mathrm{s}, \mathrm{l}}+1}
$$

where prod.comp $p_{\mathrm{s}, \mathrm{l}, \mathrm{i}}$ is the average total production of ith milk component in the lth lactation in the sth calv- 
ing system in a herd of normal lactation length, $\operatorname{dim}_{\mathrm{s}, 1}$ is the number of milking days, and prod.comp $\mathrm{s}_{\mathrm{s}, \mathrm{i}} \mathrm{CVI+1}$ is calculated as prod.comp $\mathrm{s}_{\mathrm{s}, \mathrm{l}, \mathrm{i}}$ plus the production of the ith milk component in the last day of the lth lactation in a herd of normal lactation length (e.g., milk yield, Table 8).

Seasonal-Calving Herds. In the final calculation of the fertility EV, consideration was given to the contribution of each of the above components in different calving systems. Specifically, the survival and CVI components have a much greater effect on the EV of fertility in seasonal-calving herds. The relationship between fertility and survival is nearly twice as large in herds with short CVI (e.g., seasonal-calving system) than in herds with long CVI (e.g., year-round and split-calving systems; Haile-Mariam et al., 2013). In year-round and split-calving systems, the reduction in milk production due to longer CVI is minimal and is not included in the EV for fertility in these herds because farmers will supplement cows irrespective of the calving time of the year. In seasonal-calving herds, however, late-calving cows tend to be dried off according to the curve of pasture growth; consequently, the effect of this on production can be relatively large when compared with the year-round and split-calving systems. Therefore, the EV of fertility in seasonal-calving herds accounts for the reduction in milk components production and the higher effect of fertility on survival.

EV of Temperament and Milking Speed. We based the calculation of temperament and milking speed $\mathrm{EV}$ on the expected changes in labor requirement due to variation in the proportion of problematic cows (i.e., bad temperament and slow milking cows) in the herd as a result of shifting the herd average breeding values of temperament and milking speed by 1 unit. The ABV for these traits are expressed per percentage change in temperament and milking speed, respectively.

The calculation of the EV of temperament was

$$
\begin{aligned}
& \mathrm{EV}_{\text {Temperament }}= \\
& \mathrm{EV}_{\text {Temperament }}^{\text {heifer }} \cdot \text { prop }_{\text {heifer }}+\mathrm{EV}_{\text {Temperament }}^{\text {cow }} \cdot\left(1-\text { prop }_{\text {heifer }}\right),
\end{aligned}
$$

where propheifer is the average proportion of heifers in the dairy herd, and $\mathrm{EV}_{\text {Temperament }}^{\text {heifer }}$ and $\mathrm{EV}_{\text {Temperament }}^{\text {cow }}$ are the EV of temperament for heifers and mixed-age cows, respectively. These EV were calculated as

$\mathrm{EV}_{\text {Temperament }}^{\text {heifer } / \text { cow }}=\Delta$ temp $_{\%}^{\text {heifer } / \text { cow }} \cdot \rho_{\text {Labor }}^{\text {hiifer } / \text { cow }} \cdot \mathrm{n}_{\text {milking }} \cdot \frac{\left(\text { Labor }_{\$}\right)}{60}$, where $\rho_{\text {Labor }}^{\text {heifer }}$ is the labor requirement for a bad temperament heifer or cow compared with an average heifer or cow, $n_{\text {milking }}$ is the number of milkings per cow in the respective calving interval, and Labor $\$$ average hourly labor cost (Table A1). The change in incidence of bad behavior heifers or cows after a $1 \%$ change in temperament $\mathrm{ABV}\left(\Delta \mathrm{temp}_{\%}^{\mathrm{heifer} / \mathrm{cow}}\right)$ was calculated as

$$
\begin{aligned}
& \Delta \mathrm{Temp}_{\%}^{\text {heifer } / \text { cow }}= \\
& \int \mathrm{N}\left[\mathrm{N}^{-1}\left(\operatorname{prop}_{\text {Temp }}^{\text {heifer } / \text { cow }}, 0, \mathrm{sd}_{\text {Temp }}^{\text {bulls }}\right)-1,0, \mathrm{sd}_{\text {Temp }}^{\text {bulls }}\right]-\rho_{\text {Temp }}^{\text {heifer } / \text { cow }},
\end{aligned}
$$

where prop ${ }_{\text {Temp }}^{\text {heifer/cow }}$ is the proportion of heifers or cows with bad temperament and $\mathrm{sd}_{\mathrm{Temp}}^{\text {bulls }}$ is the standard deviation of temperament $\mathrm{ABV}$ in bulls widely used within Australia.

The labor requirements of bad temperament heifer or cow compared with an average heifer or cow was calculated as

$$
\text { Labor }_{\text {Temperament }}^{\mathrm{c}}=\frac{\left(\mathrm{t}_{4 \mathrm{w}}^{\mathrm{c}} \cdot \mathrm{n}_{\text {milking-4w }}^{\mathrm{bad}}+\mathrm{t}_{\text {rest }}^{\mathrm{c}} \cdot \mathrm{n}_{\text {milking-rest }}^{\mathrm{bad}}\right)}{\mathrm{n}_{\text {milking }}},
$$

where $t_{4 \mathrm{w}}^{\mathrm{c}}$ and $\mathrm{t}_{\text {rest }}^{\mathrm{c}}$ are the extra time spent with bad behavior heifers or cows every milking during the first $4 \mathrm{wk}$ and during the rest of the lactation, respectively; $\mathrm{n}_{\text {milking-4w }}^{\text {bad }}$ and $\mathrm{n}_{\text {milking-rest }}^{\text {bad }}$ are the number of milkings when a heifer is badly behaved during the first $4 \mathrm{wk}$ and during the rest of the lactation, respectively; and $\mathrm{n}_{\text {milking }}$ is the total number of milkings. We estimated that bad temperament cows require the same extra time when milking regardless of the stage of the lactation. Therefore, Labor ${ }_{\text {Temperament }}^{\mathrm{c}}$ was calculated as the extra time spent with a bad behavior cow for the whole lactation.

The EV of milking speed ( $\left.\mathrm{EV}_{\text {Milkingspeed }}\right)$ was calculated using the same equations as for $\mathrm{EV}_{\text {Temperament }}$ but without differentiating between heifers and cows. Therefore, the parameters $\Delta$ Mspeed $_{\%}$, Labor ${ }_{\text {Mspeed }}$, $\rho_{\text {Mspeed }}$, prop Mspeed $_{\text {, }} \mathrm{sd}_{\text {Mspeed }}^{\text {bulls }}, t_{\text {slow }}$, and $n_{\text {milking }}^{\text {slow }}$ are defined in relation to the effect of milking speed and used in their respective places in equations 34,35 , and 36 (Table A1).

Note that $E V_{\text {Temperament }}$ and $E V_{\text {Milkingspeed }}$ are quite sensitive to labor requirements. Special attention has to 
be given to the calculation of these labor assumptions (Table A1) given the difficulty in quantifying the labor costs associated with these workability traits. These labor assumptions were based on feedback from farmers via the NBO review task force.

$\boldsymbol{E} \boldsymbol{V}$ of Mammary System. The EV of mammary system was calculated based on the average extra labor cost associated with difficult milking as a result of a poor mammary system (i.e., the position of teats on the udder and poor teat conformation are reasons for cups falling off). The incidence of events where cups fall off, reported below, are on a per unit of mammary system score scale. Additionally, incomplete milking and residual milk in the udder arise when cups fall off, which leads to a cost associated with an increase of mastitis cases, the EV for mammary system was calculated as

$$
\mathrm{EV}_{\text {Mammary }}=\mathrm{SLIP}_{\$}^{\text {Labor }}+\text { MASTITIS }_{\$}^{\text {Slip }}
$$

where $\mathrm{SLIP}_{\$}^{\mathrm{Labor}}$ is the cost associated with the extra labor due to cup slippage per mammary system score during the lactation of a cow, which was calculated as the overall cup slippage labor cost ( labor $_{\$}^{\text {Slip }}$ ) multiplied by the proportion of events associated with poor udder

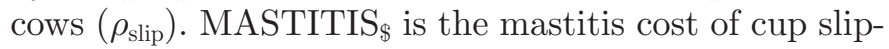
page associated with a poor mammary system during the lactation, which was calculated as

$$
\operatorname{MASTITIS}_{\$}^{\text {Slip }}=\operatorname{slip}_{\%}^{\text {Mastitis }} \cdot \mathrm{EV}_{\text {Mastitis }} \cdot \rho_{\text {slip }},
$$

where slip Mastitis is the incidence of mastitis caused by cup slippage, $\mathrm{EV}_{\text {Mastitis }}$ is the economic value of mastitis that accounts for the cost of one case of clinical mastitis ( $-\mathrm{A} \$ 106.20)$, and $\rho_{\text {slip }}$ is the proportion of poor udder cows (Table A1). Special attention has to be given to the calculation of these labor assumptions (Table A1) given the difficulty in quantifying the labor costs associated with these workability traits. These labor assumptions were based on feedback from farmers via the NBO review task force.

The EV of mastitis was based on the costs related to labor, treatment, and discarded milk as consequence of the incidence of 1 case of mastitis, and the associated recurrence, as

$$
\mathrm{EV}_{\text {Mastitis }}=\left(\text { Labor }_{\$}+\mathrm{AB}_{\$}+\text { Discmilk }_{\S}\right) \cdot \rho_{\text {incidence }},
$$

where Labor $\$$ is the average hourly labor cost, $\mathrm{AB}_{\S}$ is the antibiotic and health product costs to treat a case of mastitis, Discmilk $\mathrm{k}_{\$}$ is the milk discarded as conse- quence of the treatment, and $\rho_{\text {incidence }}$ is the proportion of reincidence in cases of cows already treated for mastitis.

EV of Overall Type, Pin Set, and Fore Udder Attachment. We calculated the EV of overall type, pin set, and fore udder attachment as a function of the economic value of survival as

$$
\begin{gathered}
\mathrm{EV}_{\text {Type }}=\mathrm{EV}_{\text {Survival }} \cdot \mathrm{b}_{\text {Survival,Type }}, \\
\mathrm{EV}_{\text {Pinset }}=\mathrm{EV}_{\text {Survival }} \cdot \mathrm{b}_{\text {Survival,Pinset }},
\end{gathered}
$$

and

$$
\mathrm{EV}_{\text {Fore Udder }}=\mathrm{EV}_{\text {Survival }} \cdot \mathrm{b}_{\text {Survival,Fore Udder }} \text {, }
$$

where $b_{\text {Survival,Type, }}, b_{\text {Survival,Pinset, }}$, and $b_{\text {Survival,Fore Udder }}$ are the genetic regression coefficients of survival on overall type, pin set, and fore udder attachment $\mathrm{ABV}$, respectively (equation 44; Table A3).

To avoid double counting, the $\mathrm{EV}_{\text {Survival }}$ was adjusted downwards by the same extent of $b_{\text {Survival,Type }} b_{\text {Survival,Pinset }}$, and $b_{\text {Survival,Fore Udder }}$ for every 1 unit increase in overall type, pin set, and fore udder attachment, respectively. The result of this adjustment has no net change in the effective weighting applied to type traits, but makes the link between these 3 type traits and the overall index more transparent.

$\boldsymbol{E} \boldsymbol{V}$ of Udder Depth. The economic value of udder depth was based on the changes in the incidence of clinical mastitis associated with changes in udder depth, calculated as

$$
\mathrm{EV}_{\text {Udder }}=\mathrm{EV}_{\text {Mastitis }} \cdot \mathrm{b}_{\text {Mastitis/Udder }} \text {, }
$$

where $b_{\text {Mastitis/Udder }}$ is the genetic regression of the change in the incidence mastitis from a change in the udder depth ABV (equation 44; Table A3).

\section{Genetic Regressions}

The calculation of EV for some traits requires the inclusion of the genetic relationship between traits, which is quantified as the genetic regressions between 2 traits. For instance, the genetic regression between trait $\mathrm{A}$ and $\mathrm{B}\left(\mathrm{b}_{\text {traitA,traitB }}\right)$ measures how trait A changes in relation to a unit change in trait $\mathrm{B}$, and was calculated as

$$
\mathrm{b}_{\text {trait } \mathrm{A}, \text { traitB }}=\frac{\mathrm{r}_{\text {traitA,traitB }} \cdot \sqrt{\left(\mathrm{h}_{\text {traitA }}^{2} \cdot \sigma_{\mathrm{p}, \text { trait } \mathrm{A}}^{2}\right)}}{\sqrt{\left(\mathrm{h}_{\text {traitB }}^{2} \cdot \sigma_{\mathrm{p}, \text { traitB }}^{2}\right)}},
$$


Table 9. Discounted genetics expressions coefficients used in the calculation of trait economic weights for the Australian dairy industry

\begin{tabular}{lc}
\hline Trait type & $\begin{array}{c}\text { Discounted genetic } \\
\text { expression coefficients }\end{array}$ \\
\hline Annual cow traits & 1.00 \\
BW traits & \\
Cow maintenance & 1.00 \\
Bobby calf value $^{2}$ & 0.71 \\
Heifer replacement feed cost & 0.34 \\
Cull cow carcass & 0.21 \\
Replacement heifer traits & 0.34 \\
End of cow life traits & 0.21 \\
\hline
\end{tabular}

${ }^{1}$ Annually expressed cow traits include all those expressed on a perlactation basis.

${ }^{2}$ Slaughter calf traits coefficients were based on birth traits multiplied by 0.6 under the assumption that $60 \%$ of all calves born become bobby calves.

where $r_{\text {traitA,traitB }}$ is the genetic correlation between trait $\mathrm{A}$ and trait $\mathrm{B}, \mathrm{h}_{\text {traitA }}^{2}$ and $\mathrm{h}_{\text {traitB }}^{2}$ are the heritabilities of traits $\mathrm{A}$ and $\mathrm{B}$, and $\sigma_{\mathrm{p}, \text { trait } \mathrm{A}}^{2}$ and $\sigma_{\mathrm{p} \text {,trait } \mathrm{B}}^{2}$ are the phenotypic variances of traits $\mathrm{A}$ and $\mathrm{B}$, respectively. Table A3 presents specific trait parameters.

\section{Derivation of EW}

The incorporation of EV into selection indices, as $\mathrm{EW}$, requires transformations to account for (a) the differences in the timing and frequencies of the expression of traits, computed by DGE coefficients (Table 9), and (b) standardized ABV units, which is done with an ABV conversion factor $\left(f_{\text {trait }}^{\mathrm{ABV}}\right.$; Table 10$)$.

Discounted genetic expression coefficients account for the proportion of superiority transmitted, in time, to an individual's descendants through the transfer of genes. The incorporation of EV into selection indices (as EW) requires differences in the timing and frequency of expression of traits to be accounted for (McClintock and Cunningham, 1974). Discounted genetic expression coefficients are calculated in the units that represent the contribution to profitability of the selection candidates' genes, so that traits expressed less frequently or very late in the lives of daughters receive less emphasis than those expressed more frequently and relatively early (Berry et al., 2006). The DGE coefficients were calculated as in Amer et al. (2001) for 10 generations over a 20-yr planning horizon using Australian dairy industry figures (Table 9). For those traits composed of various components, each of the component EV was multiplied by the respective DGE coefficient before aggregating the components into the aggregated $\mathrm{EW}$ of the trait.

Conversion factors were required to convert breeding objective trait unit definitions into ABV unit definitions. Table 10 describes the conversion factors and their application in the review of the NBO for dairy cattle in Australia. Aggregated EW were calculated by the multiplication of trait EV and their appropriate DGE coefficients, followed by the multiplication of aggregated $\mathrm{EW}$ by $\mathrm{f}_{\text {trait }}^{\mathrm{ABV}}$ factor to align relevant traits to the ABV scale.

\section{Development of Selection Indices}

Final EW were the base for the development of the selection indices for the NBO update. The development of selection indices was informed by a large-scale on-line survey of farmers' trait preferences (Martin-Collado et

Table 10. Conversion factors used to standardize units in breeding objective definition per unit change in Australian breeding value (ABV)

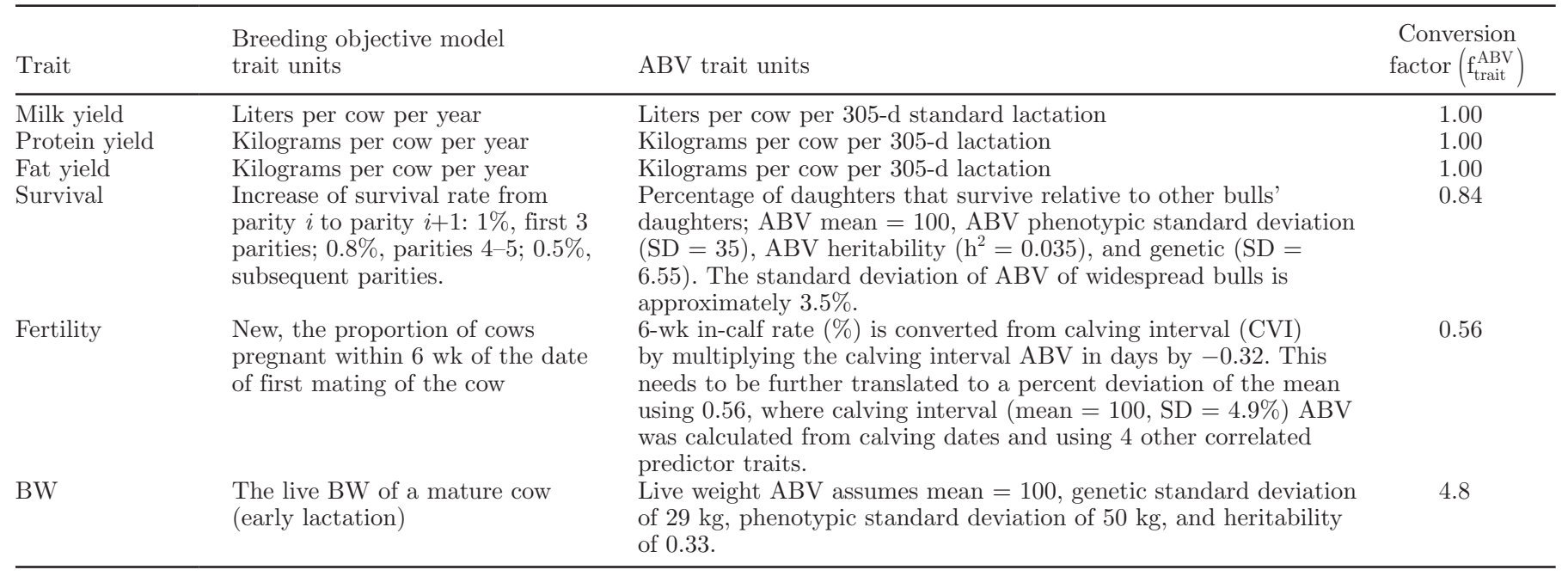


al., 2015). The aim of that study was to analyze the heterogeneity of preferences for cow trait improvements by determining whether farmer types can be identified with specific patterns of preferences. Martin-Collado et al. (2015) analyzed whether farmer types differed in farming system, socioeconomic profile, and attitudes toward breeding and genetic evaluation tools. A principal component analysis followed by a Ward hierarchical cluster analysis was used to group farmers according to their preferences. Three types of farmers were identified: (1) production-focused farmers, who gave the highest preference of all for improvements in protein yield, lactation persistency, feed efficiency, cow live weight, and milking speed; (2) functionality-focused farmers, with the highest preferences of all for improvements in mastitis, lameness, and calving difficulty; and (3) type-focused farmers, with the highest preferences of all for mammary system and type. Surprisingly, farmer types did not differ for herd size, calving and feeding system, or breed. These results support the idea that preferences for cow trait improvements are intrinsic to farmers and not to production systems or breeds. The primary index weighting of traits corresponded to the final $\mathrm{EW}$, whereas the 2 alternative indices adjusted those base weights to account for differences in farmers' preferences for trait improvements. Index changes to create the 2 alternative indices were defined by consultation with the NBO review task force. The task force was presented with index options including changes of increasing scale, which moved selection index outcomes toward the preferences of the respective group (i.e., moving further away from the final EW). Index options offered to represent the type-focused farmers included alternatives with 5, 10, and $20 \%$ less emphasis on production traits (milk, fat, and protein) and 5, 10, and $20 \%$ more emphasis on all type traits that have EW in the index. Index options offered to represent the functionality-focused farmers included alternatives with 80 , 50 , and $25 \%$ less emphasis on production traits. Note that the options presented were created not necessarily by changing the EW on the traits favored by the respective farmer group, but by changes in trait EW that affect the response to selection resulting from the use of each index. The NBO task force was also asked to consider which fertility EW (seasonal-calving system versus the average across all calving systems) should be used in each index. The development of a primary selection index and 2 alternative indices provided farmers with a range of options to choose from. Specifically, the indices were defined as (1) Balanced Performance Index (BPI), (2) Health Weighted Index (HWI), and (3) Type Weighted Index (TWI).
Responses to selection were modeled for each index using ABV from bulls born between 1990 and 2009 (n $=5,213$ ) from NASIS. Individual trait changes were modeled by regressing trait $\mathrm{ABV}$ separately on the BPI, the HWI, and the TWI, respectively. Responses are for a level of selection intensity that would achieve 100 units $(\mathrm{A} \$)$ of change in the BPI. Responses in the HWI and the TWI relative to the BPI were calculated by multiplying individual trait response, by the $\mathrm{EW}$ in the BPI.

\section{RESULTS}

Economic values, DGE coefficients, $\mathrm{f}_{\text {trait }}^{\mathrm{ABV}}$, and final EW multiplied by trait genetic standard deviations for all of the dairy traits analyzed are presented in Table 11. Relative economic weights were high for BW and milk protein, and to a lesser extent milk volume, milk fat, SCC, and survival.

Table 12 presents the specific trait weights in the indices, resulting from changes to $\mathrm{EW}$ as defined by the NBO review task force. The development of a primary selection index and 2 alternative indices provided farmers with a range of options to choose from, including the following.

(1) BPI: The primary economic index, which represented the average industry preferences and matched closely to the final EW. The seasonal calving system EW for fertility was used in the BPI.

(2) HWI: This alternative index aligned with the preferences of those farmers seeking greater focus on functionality traits, and included less emphasis on production traits (Table 12). The seasonal calving system EW for fertility was used in the HWI.

(3) TWI: This alternative index aligned with the preferences of those farmers seeking greater focus on type traits, and included less emphasis on production traits and more emphasis on all type traits (Table 12). The average across calving systems EW for fertility was used in the TWI.

Individual trait responses to selection and overall economic gains in each index relative to the BPI are presented in Table 13. The correlations between BPI and the TWI and HWI were 0.9436 and 0.9844 , respectively, when reported on a list of published Holstein bulls born between 1990 and 2009 ( $\mathrm{n}=5,213)$. All new indices will generate lesser genetic improvements in milk production traits and greater improvements 
in SCC, survival and residual survival, milking speed, overall type, mammary system, udder depth, and fore udder attachment when compared with the APR. The
TWI provides an increase in response to selection in type traits, overall type (1.86-fold increase when compared with the BPI), mammary system (1.73-fold),

Table 11. Economic values, genetic regression of component on profit traits, discounted genetic expressions (DGE) coefficients, aggregated economic weights, conversion factors, and final economic weights in the breeding objective for the Australian dairy industry

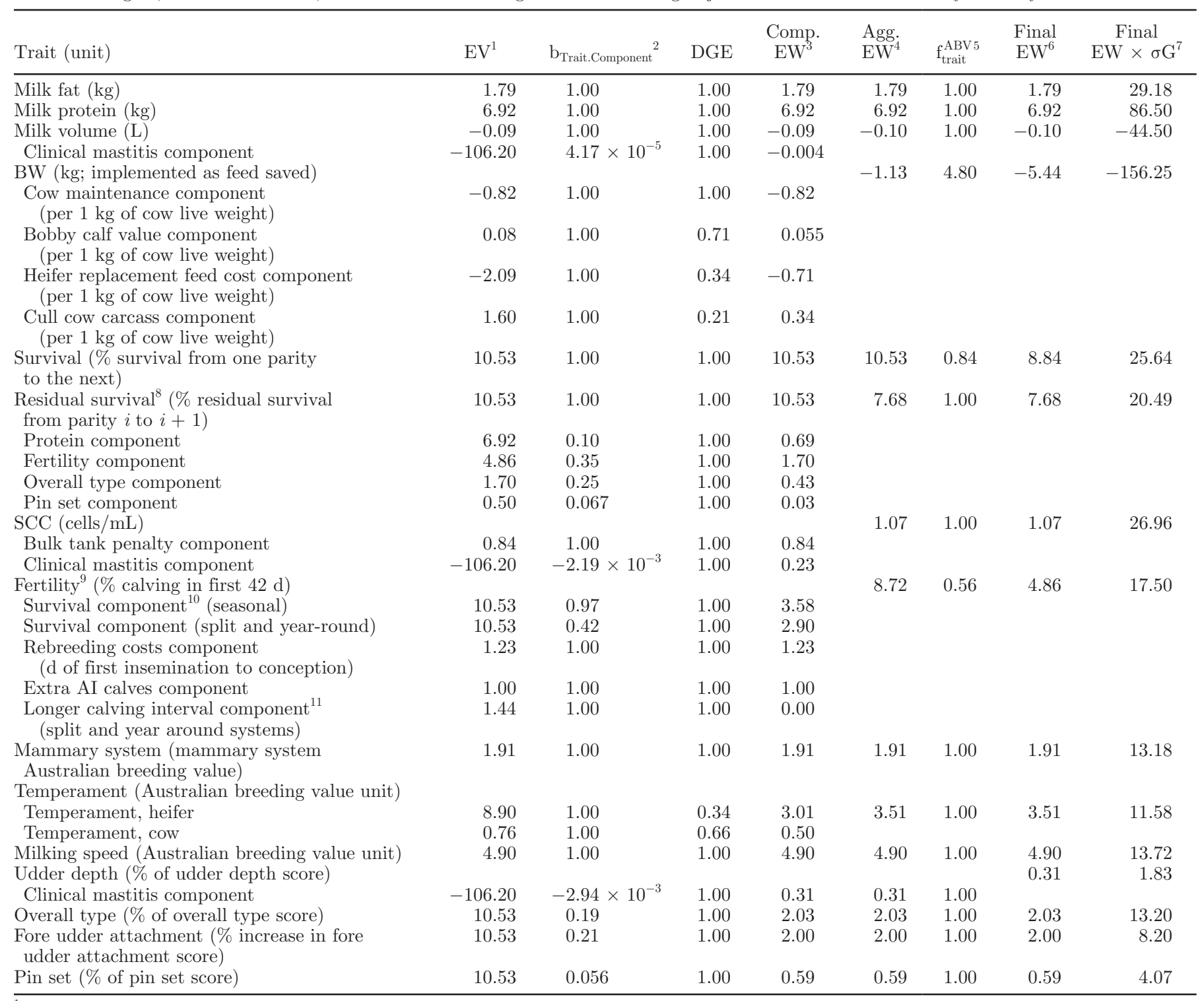

${ }^{1}$ Economic value (A $\$ /$ trait unit change).

${ }^{2}$ Genetic regression of component on profit traits.

${ }^{3}$ Component economic weight.

${ }^{4}$ Aggregated economic weight.

${ }^{5}$ Australian breeding value conversion factor.

${ }^{6}$ Final economic weight (A $\$ /$ Australian breeding value unit change).

${ }^{7}$ Variance components taken from the Australian Dairy Herd Improvement Scheme genetic evaluation system (M. Axford and G. Nieuwhof, ADHIS, Melbourne, Australia, personal communication).

${ }^{8}$ Survival after regressing out protein, fertility, overall type, and pin set.

${ }^{9}$ Fertility final economic weight in seasonal calving herds calculated at $\mathrm{A} \$ 6.94$.

${ }^{10}$ Assuming the survival component of the EV of fertility accounts for $65 \%$ of dairy farms under split and year-round calving systems and $35 \%$ under seasonal calving system. Note the higher regression coefficient between fertility and survival in seasonal-calving herds.

${ }^{11}$ The calving interval component is accounted for when calculating the EV of fertility in seasonal-calving herds. 
Table 12. Selection indices developed for the Australian National Breeding Objective update; trait weights for the primary and alternative indices

\begin{tabular}{|c|c|c|c|c|c|}
\hline Trait & $\begin{array}{c}\text { Balanced } \\
\text { performance index } \\
\text { (BPI) trait weights }{ }^{1}\end{array}$ & \multicolumn{2}{|c|}{ Type weighted index ${ }^{2}$} & \multicolumn{2}{|c|}{ Health weighted index ${ }^{3}$} \\
\hline Milk protein & 6.92 & 6.23 & -10 & 4.46 & -36 \\
\hline Milk fat & 1.79 & 1.61 & -10 & 1.16 & -35 \\
\hline Milk volume & -0.10 & -0.09 & -10 & -0.06 & -40 \\
\hline Fertility & 6.94 & 4.86 & -30 & 6.94 & 0 \\
\hline $\mathrm{SCC}$ & 1.07 & 1.07 & 0 & 1.07 & 0 \\
\hline Milking speed & 4.90 & 4.90 & 0 & 4.90 & 0 \\
\hline Temperament & 3.51 & 3.51 & 0 & 3.51 & 0 \\
\hline Mammary system & 1.91 & 2.10 & 10 & 2.48 & 30 \\
\hline Udder depth & 0.31 & 0.34 & 10 & 0.31 & 0 \\
\hline Overall type & 2.03 & 5.53 & 172 & 2.03 & 0 \\
\hline Fore-udder attachment & - & 2.20 & - & - & - \\
\hline
\end{tabular}

${ }^{1}$ This index uses fertility economic weight for a seasonal calving system instead of the average across calving systems.

${ }^{2}$ Increased emphasis on type traits and reduced emphasis in production traits.

${ }^{3}$ Reduced emphasis on production traits. This index uses fertility economic weight for a seasonal calving system instead of the average across calving systems.

udder depth (1.49-fold), and fore udder attachment (2.15-fold). The TWI provides a reduction in response to selection in feed saved when compared with the BPI. The HWI provides an increase in response to selection in SCC (1.18-fold increase when compared with the BPI), fertility (1.41-fold), survival and residual survival (1.08- and 1.35-fold, respectively), mammary system (1.05-fold), udder depth (1.36-fold), and fore udder attachment (1.24-fold). The HWI is also expected to create greater response to selection in feed saved, and a lesser response to selection in milk production traits compared with the BPI.

\section{DISCUSSION}

Historically, dairy selection indices worldwide have focused on increasing milk production and improving type traits (as indicators of cow production perfor-

Table 13. Trait responses to selection intensity required to achieve 100 units (A $\$$ ) gain in the balanced performance index (BPI), with selection on the BPI, type weighted index (TWI), health weighted index (HWI), and Australian profit rating (APR) indices, respectively ${ }^{1}$

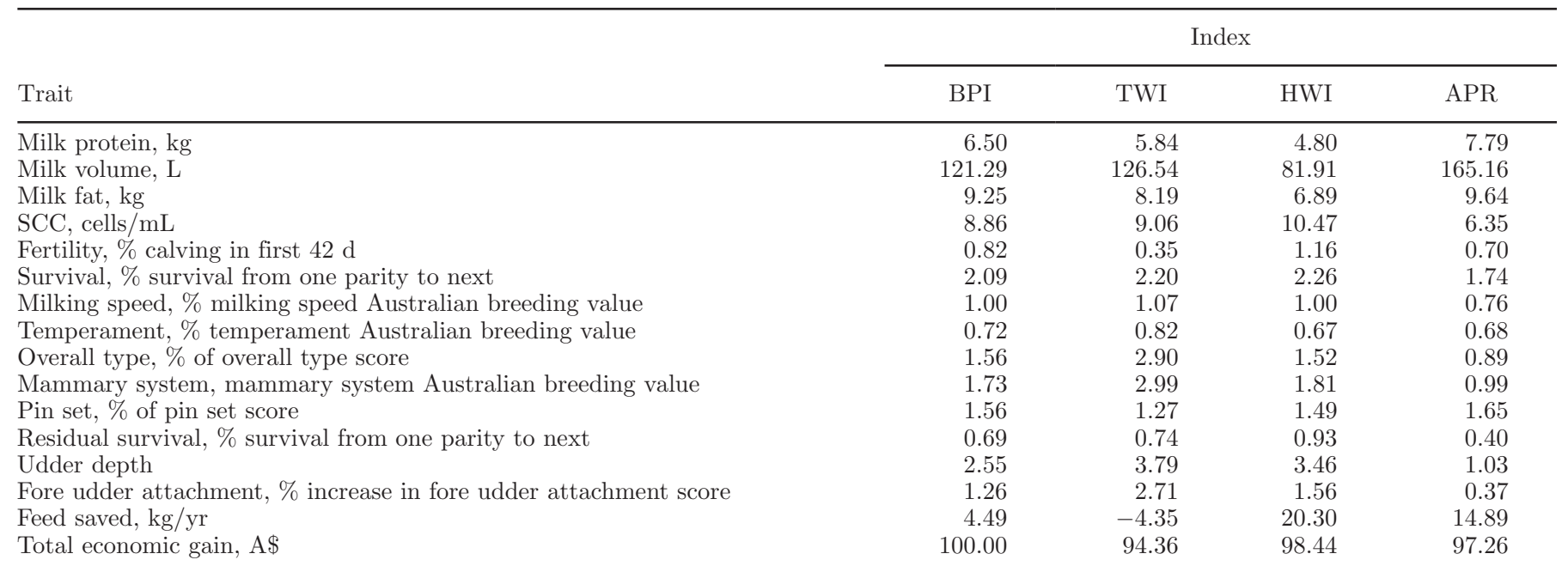

${ }^{1}$ Total economic gain is calculated using the index specific trait responses, but the gain is valued using economic weights that correspond to the BPI. 
mance), followed by the gradual inclusion of milk component traits such as protein yield and fat yield (Leitch, 1994). The first shift from this milk production-focused approach, which started some 20 yr ago in the Nordic countries and United States, to a broadening of indices to include functional traits was in response to price constraints, quota-based marketing system, and increasing producer and consumer concerns about animal health issues (Leitch, 1994; Miglior et al., 2005). A decade ago, the majority of indices in developed countries were following this more balanced approach to a greater or lesser extent (Miglior et al., 2005). A second shift in the dairy selection index paradigm, of which this paper is an example, is the acknowledgment of heterogeneity of farmers' needs and preferences for improvements in animal traits, which cannot be accounted for in a unique national index. Countries such as the United States or United Kingdom have been using various national indices for at least a decade, and this approach has been followed by other countries (Miglior et al., 2005). When a country has several indices, one is usually focused on production whereas the others focus on health or functionality traits. Usually the design of the various indices is based on variation of a primary index developed based on purely economic calculations. Variations of the primary index are based on technical criteria, expert knowledge, and sometimes on qualitative industry consultation processes. However, to our knowledge, farmers' preferences are not systematically analyzed to inform selection index development. The approach taken in this paper for the update of the Australian dairy index combined the process of calculating economic values and weights with a study that quantified Australian dairy farmers' preferences for cow trait improvements to inform and ultimately direct the choice of traits and selection indices (Martin-Collado et al., 2015).

The approach taken in our study uses economic weights, rather than selection index weights, in the creation of selection indices. The Australian Dairy Herd Improvement Scheme run separate genetic evaluations for groups of biologically correlated traits; thus, relevant correlations between traits are accounted for. Given the primary goal of the selection indices calculated here is to rank bulls for industry-wide use, the effect of correlated traits (in multitrait models) are minimal when bulls have many daughters, especially for traits where the correlation is outside the biologically evaluated groups.

The use of various breeding objectives that take into account farmers' preferences for improvements in animal traits are expected to maximize the uptake of genetics selection tools (Nielsen and Amer, 2007; Sy et al., 2011). However, we acknowledge the existence of a certain inefficiency of industry genetic progress realized by the application of 3 different indices. Therefore, as part of the formulation of new selection indices, the change in total economic gain was investigated and results indicated that modest increase in uptake of the new indices would offset the very little inefficiency in genetic progress. Therefore, the increased number of farmers adopting one of the selection indices that best suits their needs could compensate for the reranking of bulls, generating higher rates of genetic progress for the whole industry. A significant and focused extension effort will be required to ensure the correct use of the indices.

The Australian dairy production system is characterized by a remarkable diversity of feeding and calving systems. This diversity leads to variable levels of reliance on imported feed and to varying calving patterns (e.g., seasonal, split, and year-round calving). The calculation of breeding objectives and selection indices considered all of these production system factors. Compared with the previous APR index, the new primary index, BPI, is a more balanced index (includes higher weightings on functional traits), is in line with average farmers' preferences, and blends production, type, and health traits based on weighted averages of the number of farms across calving and feeding systems. The BPI and alternative indices (TWI and HWI) slow the rate of improvement for production traits compared with the APR. Conversely, they increase the rate of improvement for SCC, survival, milking speed and temperament, and fertility (in the case of BPI and HWI) and show more progress in type traits, including overall type, mammary system, udder depth (Table 13). New traits have been included to ensure the final indices are in line with farmer preferences (Martin-Collado et al., 2015); that is, mammary system, udder depth, overall type, pin set, fore-udder attachment, and residual survival. For several years, a number of type ABV have been used to predict survival, particularly in young animals. To better reflect the influence of type ABV throughout an animal's life, overall type, pin set, and udder depth have been separated from survival and included as stand-alone traits in the indices. Fore udder attachment was included in the TWI to add further weight on type and to achieve specific and desired gains in this index. Feed saved replaces BW as a more precise measure of the additional feed required by some animals. The last of the new traits is residual survival. Survival has been replaced with residual survival in all indices to ensure that the traits that contribute to survival are weighted directly in the index (e.g., overall type) and not double counted. 


\section{CONCLUSIONS}

The updated trait economic weightings resulting from the NBO review presented in this study constituted the basis of the definition for 3 new indices. The 3 indices, BPI, HWI, and TWI, have been released to the industry. There is expectation of higher uptake by farmers, who now have more choice to select an index that best matches the breeding goals for their business.

\section{ACKNOWLEDGMENTS}

The authors acknowledge Dairy Australia (Melbourne) for providing access to farmers to complete the survey, the farmers for completing the survey, and the Australian Dairy Herd Improvement Scheme (Melbourne, Australia) and Dairy Australia for funding. Jennie Pryce acknowledges financial support from Dairy Futures Cooperative Research Centre (Melbourne, Australia).

\section{REFERENCES}

Amer, P. R. 1999. Economic accounting of numbers of expressions and delays in sheep genetic improvement. N. Z. J. Agric. Res. 42:325336. http://dx.doi.org/10.1080/00288233.1999.9513382.

Amer, P. R., G. Simm, M. G. Keane, M. G. Diskin, and B. W. Wickham. 2001. Breeding objectives for beef cattle in Ireland. Livest. Prod. Sci. 67:223-239. http://dx.doi.org/10.1016/S03016226(00)00201-3.

Australian Dairy Herd Improvement Scheme (ADHIS). 2013. Australian Dairy Herd Improvement Report 2013. Accessed Nov. 11, 2015. http://www.adhis.com.au/v2/downv2.nsf/(ContentByKey)/ 0af545034ac09bf7ca2576aa001bb67a/\$file/australian\%20dairy\%20 herd\%20improvement\%20report\%202013.pdf?open.

Berry, D. P., F. E. Madalena, A. R. Cromie, and P. R. Amer. 2006. Cumulative discounted expressions of dairy and beef traits in cattle production systems. Livest. Sci. 99:159-174. http://dx.doi. org/10.1016/j.livprodsci.2005.06.006.

Byrne, T. J., P. R. Amer, P. F. Fennessy, A. R. Cromie, T. W. J. Keady, J. P. Hanrahan, and B. W. Wickham. 2010. Breeding objectives for sheep in Ireland: A bio-economic approach. Livest. Sci. 132:135-144. http://dx.doi.org/10.1016/j.livsci.2010.05.013.

CSIRO Publishing, ed. 2007. Nutrient Requirements of Domesticated Ruminants. CSIRO Publishing, Melbourne, Australia.

Dairy Australia. 2013a. Australian Dairy Industry in focus 2013. Dairy Australia, Southbank, Victoria.

Dairy Australia. 2013b. Dairy 2013 Situation and Outlook. Dairy Australia, Southbank, Victoria.

Gilmour, D., M. Ryan, C. Swann, and D. Shambrook. 2009. Dairy Industry farm monitor project 2008-2009. Department of Primary Industries, Rutherglen, Victoria, Australia.

Haile-Mariam, M., P. J. Bowman, and J. E. Pryce. 2013. Genetic analyses of fertility and predictor traits in Holstein herds with low and high mean calving intervals and in Jersey herds. J. Dairy Sci. 96:655-667. http://dx.doi.org/10.3168/jds.2012-5671.

Haile-Mariam, M., O. Gonzalez-Recio, and J. E. Pryce. 2014. Prediction of liveweight of cows from type traits and its relationship with production and fitness traits. J. Dairy Sci. 97:3173-3189. http:// dx.doi.org/10.3168/jds.2013-7516.

Harris, B., J. E. Pryce, and W. A. Montgomerie. 2007. Experiences from breeding for economic efficiency in dairy cattle. Proc. Adv. Anim. Breed. Genet. 17:434-444.

Hill, W. G. 1974. Prediction and evaluation of response to selection with overlapping generations. Anim. Prod. 18:117-139. http:// dx.doi.org/10.1017/S0003356100017372.

James, J. 1980. Index selection for simultaneous improvement of several characters. Pages 221-229 in Proceedings of the 14th International Congress of Genetics. Vol. 1, Book 2. MIR Publishers, Moscow, Russia.

Leitch, H. W. 1994. Comparison of international selection indices for dairy cattle breeding. Proceedings of the Annual Interbull Annual Meeting (10), Ottawa, Canada.

Martin-Collado, D. T. J. Byrne, P. R. Amer, B. F. S. Santos, M. Axford, and J. E. Pryce. 2015. Analyzing the heterogeneity of farmers' preferences for improvements in dairy cow traits using farmer typologies. J. Dairy Sci. 98:4148-4161. http://dx.doi.org/10.3168/ jds.2014-9194.

McClintock, A. E., and E. P. Cunningham. 1974. Selection in dual purpose cattle populations: Defining the breeding objective. Anim. Prod. 18:237-247.

Miglior, F., B. L. Muir, and B. J. Van Doormaal. 2005. Selection indices in Holstein cattle of various countries. J. Dairy Sci. 88:12551263. http://dx.doi.org/10.3168/jds.S0022-0302(05)72792-2.

MLA. 2014. Australian livestock export, industry statistical review 2013. February 2014. Meat and Livestock Australia. Accessed Aug. 1, 2016. http://www.livecorp.com.au/LC/files/14/145db74f-513749b3-88c3-0c5b5d8c63d9.pdf.

Murphy, R., and G. Simpson. 2013. Queensland Dairy Accounting Scheme 2013: Balancing dairy production and profits in northern Australia. Department of Agriculture, Fisheries and Forestry, Toowoomba, Queensland, Australia.

Nielsen, H. M., and P. R. Amer. 2007. An approach to derive economic weights in breeding objectives using partial profile choice experiments. Animal 1:1254-1262. http://dx.doi.org/10.1017/ S1751731107000729.

Pryce, J. E., O. Gonzalez-Recio, G. Nieuwhof, W. J. Wales, M. P. Coffey, B. J. Hayes, and M. E. Goddard. 2015. Hot topic: Definition and implementation of a breeding value for feed efficiency in dairy cows. J. Dairy Sci. 98:7340-7350. http://dx.doi.org/10.3168/ jds.2015-9621.

Pryce, J. E., J. H. J. van der Werf, M. Haile-Mariam, B. Malcolm, and M. E. Goddard. 2009. Updated index weights for the Australian Profit Ranking in dairy cattle. Proc. Assoc. Adv. Anim. Breed. Genet. 18:143-146.

Sy, H. A., M. D. Faminow, G. V. Johnson, and G. Crow. 2011. Estimating the values of cattle characteristics using an ordered probit model. Am. J. Agr. Econ. 79:463-476.

Veerkamp, R. F., P. Dillon, E. Kelly, A. R. Cromie, and A. F. Groen. 2002. Dairy cattle breeding objectives combining yield, survival and calving interval for pasture-based systems in Ireland under different milk quota scenarios. Livest. Prod. Sci. 76:137-151. http:// dx.doi.org/10.1016/S0301-6226(02)00006-4. 


\section{APPENDIX}

Base input parameters are shown in Table A1. Assumptions and base calculations of feed requirement for growth to inform the calculation of the economic value of the heifer replacement feed cost component of mature BW are seen in Table A2.

\section{Assumptions and Calculations of the EV of Fertility (Rebreeding Costs Component)}

The change in $\mathrm{AI}$ cost after the $1 \% \mathrm{CR}_{42}$ (difference in conception rate at d 42) increase change $\left(\Delta \mathrm{AI}_{\$}\right)$ used in the calculation of the rebreeding costs component of fertility EV was calculated as described below:

$$
\Delta \mathrm{AI}_{\S}=\mathrm{AI}_{\$}-\mathrm{AI}_{\$}^{+1 \%}
$$

where $\mathrm{AI}_{\$}$ and $\mathrm{AI}_{\$}^{+1 \%}$ are the cost of $\mathrm{AI}$ and overall breeding and rebreeding costs in an average dairy herd, and in the herd where fertility is improved by $1 \%$, respectively.

The cost of AI over multiple cycles was calculated as

$$
\mathrm{AI}_{\$}^{\mathrm{i}}=\sum_{\mathrm{c}=1}^{10}\left(\mathrm{ai}_{1}^{\$}+\mathrm{N}_{\mathrm{i}=\mathrm{n}} \times a \mathrm{i}_{\mathrm{n}}^{\$}\right)
$$

where $\mathrm{ai}_{1}^{\$}$ and $\mathrm{ai}_{\mathrm{n}}^{\$}$ are the cost of the first and subsequent insemination events respectively, and $\mathrm{N}_{\mathrm{i}=\mathrm{n}}$ is the proportional number of inseminations on each respective cycle, defined as the resulting probability of a new insemination after accounting for the pregnancy $\left(\mathrm{cr}_{\mathrm{AI}}\right)$ and heat detection $\left(\mathrm{dr}_{\mathrm{AI}}\right)$ rates, as described below. Table A3 describes the basic parameters used to calculate insemination costs:

$$
\mathrm{N}_{\mathrm{i}=\mathrm{n}}=\mathrm{N}_{\mathrm{n}-1} \times \mathrm{cr}_{\mathrm{AI}} \times \mathrm{dr}_{\mathrm{AI}} .
$$

Genetic regressions parameters are shown in Table

\begin{tabular}{|c|c|c|c|}
\hline Parameter & Acronym & Value & Applied to trait \\
\hline Average energy content of feed, ${ }^{4} \mathrm{MJ}$ of $\mathrm{ME} / \mathrm{kg}$ of $\mathrm{DM}$ & energy $_{j}^{\text {feed }}$ & 11.9 & Feed cost \\
\hline Average feed price, ${ }^{4} \mathrm{~A} \$ / \mathrm{kg}$ of $\mathrm{DM}$ & $\operatorname{price}_{j}^{\text {feed }}$ & 0.286 & \\
\hline $\begin{array}{l}\text { Number of herd recorded dairy cows per region }{ }^{5} \\
\text { Victoria } \\
\text { New South Wales } \\
\text { Queensland } \\
\text { South Australia } \\
\text { Tasmania } \\
\text { Western Australia }\end{array}$ & $\mathrm{n}_{\mathrm{j}}^{\text {cows }}$ & $\begin{array}{r}433,383 \\
99,919 \\
38,587 \\
46,928 \\
58,766 \\
30,236\end{array}$ & Feed cost/milk EV \\
\hline $\begin{array}{l}\text { Cull cow average price, } \mathrm{A} \$ / \mathrm{kg} \text { of cow } \mathrm{BW} \text { by lactation } \\
\text { Cull cow average dressing out, } \%\end{array}$ & $\begin{array}{l}\operatorname{cwt}_{\$} \\
\mathrm{dp}_{\%}\end{array}$ & $\begin{array}{l}2.68 \\
55.6\end{array}$ & Survival EV \\
\hline $\begin{array}{l}\text { Number of herd recorded dairy cows per region breed } \\
\text { Holstein-Friesian } \\
\text { Jersey } \\
\text { Crossbreed and others }\end{array}$ & $\mathrm{n}_{\mathrm{b}}$ & $\begin{array}{r}339,438 \\
54,089 \\
75,720\end{array}$ & BW EV \\
\hline $\begin{array}{l}\text { Average herd recorded cow milk production per lactation, } \mathrm{L} \\
\text { Change in SCC ABV for a 50,000 increase in cell count }\end{array}$ & $\begin{array}{l}\text { milk.prod } \\
\Delta \operatorname{scc}_{\mathrm{BV}}\end{array}$ & $\begin{array}{l}6,788 \\
-31.25\end{array}$ & SCC EV \\
\hline $\begin{array}{l}\text { Proportion of cows per calving system } \\
\text { Split calving }\end{array}$ & $\rho_{\mathrm{cs}}^{\mathrm{SC}}$ & 0.416 & Fertillty EV \\
\hline Year-round calving & $\rho_{\mathrm{cs}}^{\mathrm{Y}}$ & 0.234 & \\
\hline
\end{tabular}
A4.

Table A1. Base input parameters for the calculation of economic values 
Table A1 (Continued). Base input parameters for the calculation of economic values

\begin{tabular}{|c|c|c|c|}
\hline Parameter & Acronym & Value & Applied to trait \\
\hline $\begin{array}{l}\text { Calf mortality, } \% \\
\text { Genetic merit differential of AI calves over natural mating calves, A } \$ \\
\text { Price differential of AI calves over natural mating calves, A } \$ \\
\text { Price of beef bull sired female calf, A } \$ / \text { calf }\end{array}$ & $\begin{array}{l}\text { mort }_{\text {calf }} \\
\triangle \mathrm{APR}_{\text {fert }} \\
\Delta \mathrm{AB} \\
\text { calf.females }_{\$}^{\text {beef }}\end{array}$ & $\begin{array}{l}5 \\
62.7 \\
435 \\
100\end{array}$ & \\
\hline Price of beef bull sired male calf, $\mathrm{A} \$ /$ calf & calf.male $_{\$}^{\text {beef }}$ & 30 & \\
\hline Extra labor required by a bad temperament heifer, ${ }^{8}$ minutes per heifer per milking & $\rho_{\text {Labor }}^{\text {heifer }}$ & 0.48 & Temperament EV \\
\hline Extra labor required by a bad temperament $c$ ow ${ }^{9}$ minutes per cow per milking & $\rho_{\text {Labor }}^{\text {cow }}$ & 0.33 & \\
\hline Number of milkings per cow & $\mathrm{n}_{\text {milking }}$ & 644 & \\
\hline Proportion of heifers with bad temperament & prop peifer $_{\text {Temp }}$ & 0.096 & \\
\hline $\begin{array}{l}\text { Extra time spent with bad behavior heifers or cows every milking during the rest } \\
\text { of } \\
\text { the lactation, min }\end{array}$ & $\mathrm{t}_{\text {rest }}^{\mathrm{c}}$ & 0.33 & \\
\hline $\begin{array}{l}\text { Number of milkings when a heifer is badly behaving during the first } 4 \text { wk of } \\
\text { lactation }\end{array}$ & $\mathrm{N}_{\text {milking-4w }}^{\text {bad }}$ & 56 & \\
\hline Number of milkings when a heifer is badly behaving during the rest of lactation & $\mathrm{N}_{\text {milking-rest }}^{\text {bad }}$ & 588 & \\
\hline Average hourly labor cost, $\mathrm{A} \$ / \mathrm{h}$ & labor $_{\$}$ & 30 & $\begin{array}{l}\text { Temperament EV/ } \\
\text { milking speed EV/ } \\
\text { mammary system }\end{array}$ \\
\hline $\begin{array}{l}\text { Extra labor required by low milking speed cow, min per cow per milking } \\
\text { Proportion of low milking speed cows }\end{array}$ & $\begin{array}{l}\rho_{\text {Mspeed }} \\
\text { prop }_{\text {Mspeed }}\end{array}$ & $\begin{array}{l}1.5 \\
0.015\end{array}$ & Milking speed EV \\
\hline Standard deviation of milking speed ABV in bulls & $\mathrm{sd}_{\text {Mspeed }}^{\text {bulls }}$ & 2.41 & \\
\hline
\end{tabular}

${ }^{1}$ Average across 4- to 5-yr historical prices plus an upcoming season forecast, weighed across regions.

${ }^{2}$ Source: CSIRO Publishing (2007).

${ }^{3}$ Feed costs were used frequently in the calculations of the economic values of different traits within the bio-economic model.

${ }^{4}$ Energy content and prices averaged across different regions of Australia weighted by the number of dairy cows in each region. Source: Gilmour et al. (2009) and Murphy and Simpson (2013).

${ }^{5}$ Dairy Australia (2013a) and ADHIS (2013).

${ }^{6}$ Dairy Australia (2013b) and ADHIS (2013).

${ }^{7} \mathrm{SCC}$ Australian breeding values (ABV) expressed as a percentage of the mean SCC $(160,000$ cells/mL), modeled as a change of 50,000 SCC, which represents $31.25 \%$ of the mean; for the $\mathrm{SCC} \mathrm{ABV}$, a positive value is favorable.

${ }^{8}$ Based on a problem heifer requiring 2 min per milking for 4 wk (56 milking events) and $20 \mathrm{~s}$ per milking for the remainder of the lactation (588 milking events).

${ }^{9}$ Based on a problem cow requiring 20 s per milking.

${ }^{10} 30 \mathrm{~s}$ assumed to be required to address a slipping cups event. 
Table A2. Heifer replacement feed requirement for growth by cow age period and breed, and feed costs by breed for base herd and mature BW and for herd with a 1-kg increase in mature BW

\begin{tabular}{|c|c|c|c|c|c|c|c|c|}
\hline \multirow[b]{2}{*}{ Cow age period } & \multirow{2}{*}{$\begin{array}{l}\text { Target heifer } \\
\text { live weight, } \\
\% \text { of total } \\
\text { cow LWT }{ }^{1}\end{array}$} & \multirow{2}{*}{$\begin{array}{c}\text { Growth energy } \\
\text { Requirements, } \\
\text { MJ of ME } / \mathrm{kg} \\
\text { of } \mathrm{LWT}^{2}\end{array}$} & \multicolumn{3}{|c|}{$\begin{array}{c}\text { Base }^{\mathrm{LWT}} \text {, } \\
\text { MJ of ME per period }\end{array}$} & \multicolumn{3}{|c|}{$\begin{array}{c}\text { Base }^{\mathrm{LWT}+1 \mathrm{~kg}}, \\
\text { MJ of ME per period }\end{array}$} \\
\hline & & & $\begin{array}{l}\text { Holstein- } \\
\text { Friesian }\end{array}$ & Jersey & $\begin{array}{l}\text { Crossbreed } \\
\text { and others }\end{array}$ & $\begin{array}{l}\text { Holstein- } \\
\text { Friesian }\end{array}$ & Jersey & $\begin{array}{l}\text { Crossbreed } \\
\text { and others }\end{array}$ \\
\hline $3 \mathrm{mo}$ & 20 & 14.2 & 1,790 & 1,383 & 1,601 & 1,793 & 1,386 & 1,604 \\
\hline $6 \mathrm{mo}$ & 30 & 17.9 & 1,587 & 1,226 & 1,419 & 1,589 & 1,229 & 1,422 \\
\hline $9 \mathrm{mo}$ & 40 & 24.7 & 4,609 & 3,562 & 4,123 & 4,617 & 3,570 & 4,130 \\
\hline $21 \mathrm{mo}$ & 86 & 33.2 & 10,602 & 8,194 & 9,483 & 10,619 & 8,211 & 9,500 \\
\hline $24 \mathrm{mo}$ & 90 & 33.2 & 8,152 & 6,300 & 7,291 & 8,165 & 6,313 & 7,304 \\
\hline$>24 \mathrm{mo}^{3}$ & 100 & 33.2 & 12,686 & 9,804 & 11,346 & 12,706 & 9,825 & 11,367 \\
\hline $\begin{array}{l}\text { Total energy } \\
\text { requirements for growth } \\
\text { (energy.req Growth })^{3}\end{array}$ & & & 54,638 & 42,226 & 48,868 & 54,725 & 42,313 & 48,955 \\
\hline Number of cows $\left(n_{b}\right)$ & & & 339,438 & 54,089 & 75,720 & 339,438 & 54,089 & 75,720 \\
\hline
\end{tabular}

${ }^{1} 628,486$, and $562 \mathrm{~kg}$ for Holstein-Friesian, Jersey, and crossbred cows, respectively. LWT = live weight.

${ }^{2}$ Source: Farm Monitor Project VIC (2008/09 to 2012/13) and NSW (2011/12 and 2012/13), Queensland Dairy Accounting Scheme Report 2013.

${ }^{3}$ The total growth feed costs to rear a heifer replacement to heavier live weight targets up to $730 \mathrm{~d}$ of age. Source: CSIRO, 2007.

Table A3. Parameters used to calculate genetic regressions between traits

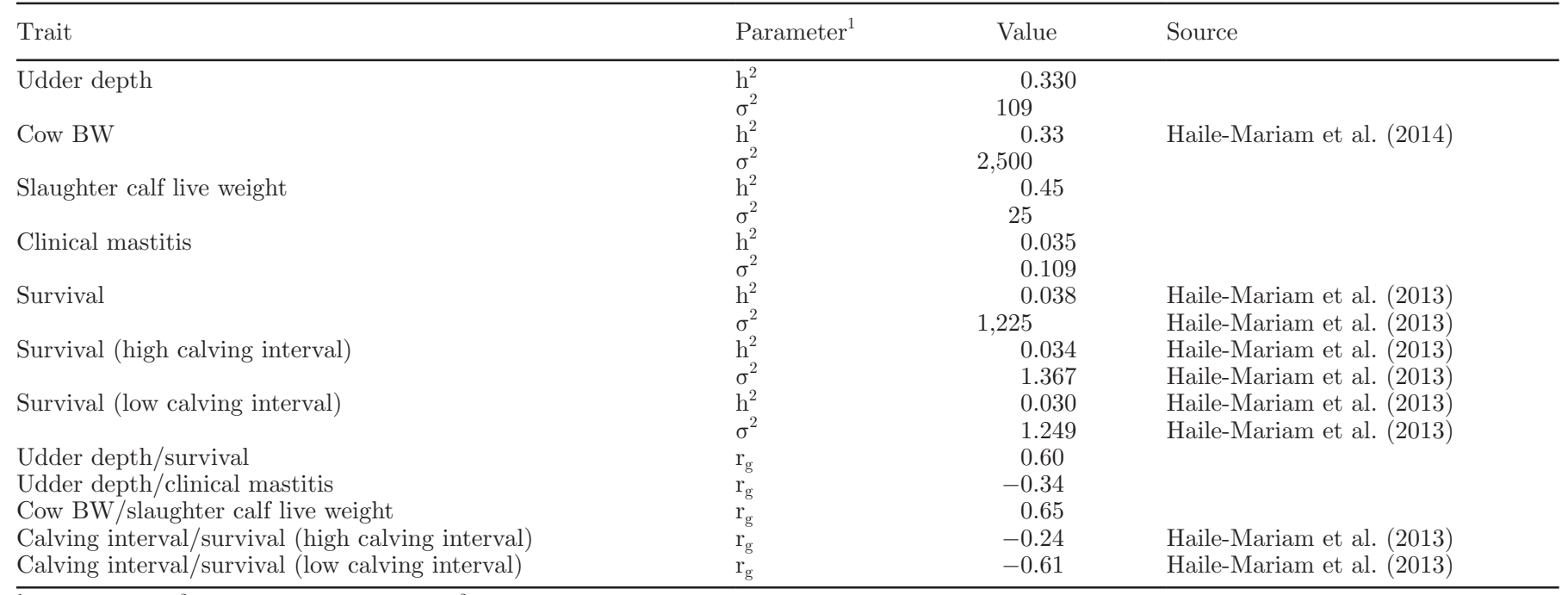

${ }^{1}$ Heritability $\left(\mathrm{h}^{2}\right)$, phenotypic variance $\left(\sigma^{2}\right)$, and genetic correlation $\left(\mathrm{r}_{\mathrm{g}}\right)$ between traits. 
Table A4. Parameters used to calculate change in rebreeding costs with a change of $1 \%$ in herd fertility ${ }^{1}$

\begin{tabular}{lc}
\hline Parameter & Value \\
\hline Average heat detection rate, \% & 0.80 \\
Average conception rate using conventional AI, \% & 0.43 \\
Average conception rate using sexed semen for AI, \% & 0.32 \\
Number of inseminations AI events weighted average & 1.29 \\
Cost of conventional semen, A $\$ /$ straw & 20.0 \\
Cost of sexed semen, A $\$ /$ straw & 50.0 \\
Costs of cow service, ${ }^{,} \mathrm{A} \$ /$ service & 19.4 \\
Costs per AI event, ${ }^{2} \mathrm{~A} \$ / \mathrm{AI}$ event & 40.2 \\
Rebreeding costs, ${ }^{4} \mathrm{~A} \$ /$ rebreeding & 26.9 \\
Percentage of AI events, conventional (unsexed) semen, $\%$ & 94.2 \\
Percentage of AI events using sexed semen, \% & 4.0 \\
Assumed heat detection in first cycle, \% & 90.0 \\
\hline
\end{tabular}

${ }^{1}$ Data obtained with collaboration from 5 experts in the area of artificial breeding of dairy cattle in Australia.

${ }^{2}$ Includes vet and farm worker time for heat detection but excludes AI costs.

${ }^{3} \mathrm{M}$. Axford (ADHIS, Melbourne, Australia, personal communication), 5 industry experts, and Dairy Farm Monitor Project - Victoria and New South Wales Annual Reports 2012/13, referring to costs with AI and herd test, discounting herd test and semen costs.

${ }^{4}$ Average semen price multiplied by the overall average number of inseminations. 